\title{
Environmental life cycle assessment of Italian mozzarella cheese: Hotspots and improvement opportunities
}

\author{
A. Dalla Riva, ${ }^{*}$ J. Burek, $\dagger$ D. Kim, $\dagger$ G. Thoma, $\dagger$ M. Cassandro, ${ }^{*}$ and M. De Marchi ${ }^{* 1}$ \\ *University of Padova, Department of Agronomy, Food, Natural Resources, Animals and Environment, Viale dell'Università 16, \\ 35020 Legnaro (PD), Italy \\ †Ralph E. Martin Department of Chemical Engineering, University of Arkansas, 3202 Bell Engineering Center, Fayetteville, 72701-1201
}

\begin{abstract}
The present study investigated a cradle-to-grave life cycle assessment to estimate the environmental impacts associated with Italian mozzarella cheese consumption. The differences between mozzarella produced from raw milk and mozzarella produced from curd were studied, and differences in manufacturing processes have been emphasized in order to provide guidance for targeted improvements at this phase. Specifically, the third-largest Italian mozzarella producer was surveyed to collect site-specific manufacturing data. The Ecoinvent v3.2 database was used for secondary data, whereas SimaPro 8.1 was the modeling software. The inventory included inputs from farm activities to end of life disposal of wasted mozzarella and packaging. Additionally, plant-specific information was used to assign major inputs, such as electricity, natural gas, packaging, and chemicals to specific products; however, where disaggregated information was not provided, milk solids allocation was applied. Notably, loss of milk solids was accounted during the manufacture, moreover mozzarella waste and transport were considered during distribution, retail, and consumption phases. Feed production and animal emissions were the main drivers of raw milk production. Electricity and natural gas usage, packaging (cardboard and plastic), transport, wastewater treatment, and refrigerant loss affected the emissions from a farm gate-to-dairy plant gate perspective. Post-dairy plant gate effects were mainly determined by electricity usage for storage of mozzarella, transport of mozzarella, and waste treatment. The average emissions were $6.66 \mathrm{~kg}$ of $\mathrm{CO}_{2}$ equivalents and 45.1 MJ of cumulative energy demand $/ \mathrm{kg}$ of consumed mozzarella produced directly from raw milk, whereas mozzarella from purchased curd had larger emissions than mozzarella from raw milk due to added transport
\end{abstract}

Received December 3, 2016.

Accepted June 6, 2017.

${ }^{1}$ Corresponding author: massimo.demarchi@unipd.it of curd from specialty manufacturing plants, as well as electricity usage from additional processes at the mozzarella plant that are required to process the curd into mozzarella. Normalization points to ecotoxicity as the impact category most significantly influenced by mozzarella consumption. From a farm gate-to-grave perspective, ecotoxicity and freshwater and marine eutrophication are the first and second largest contributors of mozzarella consumption to average European effects, respectively. To increase environmental sustainability, an improvement of efficiency for energy and packaging usage and transport activities is recommended in the post-farm gate mozzarella supply chain.

Key words: carbon footprint, climate change, energy use, dairy industry

\section{INTRODUCTION}

Cheese is a strategic way to conserve milk and represents a food with great nutritional value, as it contains proteins, EAA, minerals, vitamins, and milk fat; it has large economic value and its international production and trade are both increasing (CLAL, 2016). In recent years, the environmental consequences of dairy production are being considered at the policy level and in the development of new production technologies, in addition to economic, nutritional, and social values. Importantly, environmental sustainability is gaining more attention from producers and consumers, with aims of increased efficiency and new market areas on the one hand and environmental care by saving natural resources on the other hand. Modifications in dairy production facilities and studies (Berlin, 2002; Milani et al., 2011; Kim et al., 2013) have been made to increase environmental sustainability in dairy chain production, with each operator along the supply chain contributing to the reduction the environmental burden.

Mozzarella cheese is consumed worldwide and can be produced using bovine or water buffalo milk, with the former being the most produced and commercialized. Growth in bovine milk mozzarella production is 
projected for the future, whereas mozzarella continues to be a strategic product for the global dairy sector (Koeleman, 2015). Italy is one of the major cow milk mozzarella producers and consumers, evidenced by $253,000 \mathrm{t}$ of mozzarella produced in Italy in 2015 and $4.6 \mathrm{~kg}$ per capita per year consumed (Assolatte, 2015). Furthermore, mozzarella production is a complex process, including several operations and numerous inputs and outputs, which in turn result in various environmental impacts. Notably, limited information exists on environmental impacts derived from mozzarella production and consumption in the Italian sector. Therefore, our study aims to increase the knowledge of environmental consequences of mozzarella production and consumption from a life cycle perspective. Mozzarella is produced in 2 different ways: the most traditional mozzarella (high-moisture mozzarella) is manufactured using raw milk directly, which is worked and transformed into mozzarella in the same mozzarella plant; otherwise, mozzarella can be produced using purchased curd, which is a semifinished product made in a different dairy plant and is purchased by the mozzarella plant to manufacture the mozzarella. The latter method produces low-moisture mozzarella, which is generally used as an ingredient in prepared dishes rather than consumed fresh.

Life cycle assessment (LCA), based on ISO 14040 and ISO 14044 LCA methodology (ISO 2006a,b), is a scientific method recognized worldwide to assess environmental burdens through the life cycle of a product; it has been used in several studies to assess environmental consequences of cheese production. Some authors (González-García et al., 2013a,b; Broekema and Kramer, 2014; Trevisan and Corrado, 2014; Finnegan et al., 2015) have investigated environmental impacts in the cheese life cycle, where general results show dairy farm activities and feed production as the main hot spots for impacts, followed by the manufacturing, distribution, and consumption phases. Fewer studies specifically assess the effect of the mozzarella life cycle. Palmieri et al. (2016) reported raw milk production as the main driver for several impacts along the Italian mozzarella production chain, whereas thermal energy to produce steam and hot water contributed to impacts arising during mozzarella manufacturing, particularly human toxicity, eutrophication, and ozone depletion. Nevertheless, Palmieri et al. (2016) focused on farm production, so little information was presented for manufacturing, and no information was provided on the distribution, consumption, and disposal phases. The only other LCA case study of Italian mozzarella was an assessment conducted to obtain an ecolabel for a private dairy company (EPD, 2013), where raw milk production, packaging, manufacturing, and home refrigeration were the main hotspots. Similarly, Kim et al. (2013) investigated the production of American mozzarella cheese, reporting that cattle feed production and farm milk production were the major contributors to most of the impact categories; whereas for the post-farm supply chain, cheese manufacturing drove several effects, followed by retail and consumption. Additionally, electricity and natural gas consumption were found to be drivers of climate change, cumulative energy demand, human toxicity, and ecotoxicity, whereas transportation influencing photochemical oxidant formation and on-site wastewater treatment were the main causes of eutrophication effects. Vergé et al. (2013) included mozzarella cheese in the LCA of Canadian dairy products, however, their study estimated only the greenhouse gases emissions, and the system boundaries excluded all the phases after dairy plant and the solid waste treatment; moreover, the study did not characterize the specific environmental impacts of mozzarella, but it was inserted into a generic cheese category without differentiation from cheddar, specialty cheeses, or processed cheese. Additionally, Nielsen and Høier (2009) studied the change of environmental impact using different enzymes during mozzarella manufacturing; thus, great attention was given to different manufacturing technologies, yet no information was given for environmental impacts of mozzarella consumption.

In light of this gap in the available literature, the objective of our study was to investigate the environmental impacts that occur during the life cycle of cow milk mozzarella (mozzarella from raw milk) production, from cradle-to-grave, with a strong emphasis on the manufacturing plant, which may in turn help producers highlight inefficiencies during manufacturing for the purpose of increasing environmental sustainability. In addition, our study investigates the environmental burdens of producing mozzarella from purchased curd, as no studies were found on this type of product, even though it has an important market share. Overall, the results from our study may help guide production decisions on mozzarella technologies and production.

\section{MATERIALS AND METHODS}

\section{Goal and Scope Definition}

The main goal of our study was to estimate the environmental impacts from mozzarella production and consumption. This estimation should assist the Italian dairy industry by providing environmental information of Italian dairy products that highlight opportunities for increasing the sustainability of the Italian dairy sector. To showcase these effects, an LCA based on ISO 14040 and ISO 14044 methodology (ISO 2006a,b) was 
performed, with the scope of the study being a cradleto-grave assessment. Specific emphasis was given to the manufacturing process, which encompasses raw milk transport through delivery of mozzarella to the customer. Specifically, our study estimated the effects of the 2 types of commonly produced Italian mozzarella (Assolatte, 2015): high-moisture (HM) mozzarella (62.5\% moisture content), which is produced directly from raw milk, and low-moisture (LM) mozzarella (52\% moisture content), which is manufactured using purchased curd. Our study primarily focused on the impacts of HM mozzarella (68\% of Italian mozzarella production); however, a scenario analysis has been performed to compare HM and LM mozzarella. Life cycle inventory for each type of mozzarella is shown in the Materials and Methods section, whereas the comparison between mozzarella types is presented in the Discussion section.

According to the Codex Standard 262-2006 (FAO, 2006), mozzarella is an unripened, near-white color, smooth elastic cheese, characterized by a long-stranded, parallel oriented, fibrous protein structure without evidence of curd granules and is also rindless. Mozzarella is made using cow or buffalo milk, or mixtures of the 2 . Moreover, mozzarella is produced as 2 main types: high moisture content mozzarella, which is a soft cheese with overlapping layers that may form pockets containing a liquid of milky appearance, and can be packaged with or without brine (a preserving liquid); or low moisture content mozzarella with a firm or semihard homogeneous structure without holes, suitable for shredding. Mozzarella is manufactured by pasta filata processing, where the curd of a suitable $\mathrm{pH}$ is heated, kneaded, and stretched until it is smooth and free from lumps. After that, the warm curd is cut and molded, and then firmed by cooling.

\section{Functional Unit}

The functional unit was $1 \mathrm{~kg}$ of HM mozzarella produced in Italy and consumed in Italy and abroad (wet basis: $62.5 \%$ moisture content). A scenario was also prepared to compare HM mozzarella with LM mozzarella, and for this scenario we used DM content as the functional unit to avoid bias due to differences in moisture content.

\section{System Boundaries}

The system boundaries encompassed raw milk production (feed production and on-farm activities), raw milk transport, mozzarella manufacturing, transport of mozzarella, packaging, distribution, retail, consumption, and disposal (Figure 1). Infrastructure was included in the system boundaries, but employee commuting and other ancillary activities were not considered (Kim et al., 2013). Although the LCA was a cradle-to-grave analysis, emphasis was given to manufacturing plant and processes. All the quantifiable material and energy flows were considered in the facility inventory and impact assessment. To reach the highest resolution in the description of mozzarella production, the individual manufacturing operations were characterized by energy, heat, or material requirements, whereas plant-specific information was used to assign specific inputs to each product. Importantly, our study is not a detailed engineering analysis, and some information was available only at the whole-plant scale, not directly assigned to a specific operation.

\section{Allocation}

Allocation at the dairy farm level was performed using the IDF (2015) methodology, where the emissions are allocated between milk and animal live weight, considering the energy content of the feed required to produce each product (Dalla Riva et al., 2015). Fat, protein, lactose, and ash are the main solid components in milk (Walstra et al., 2006) and in mozzarella cheese, so it is reasonable to consider the movement of milk solids through the plant as a factor to allocate resources and environmental burdens to mozzarella and co-products. The choice of allocation model can influence the assessment results (Flysjö et al., 2011); therefore, in our study, allocation was still required because many of the operations, such as pasteurization, are relevant for all of the valuable products, although data were provided for individual operations within the facility rather than for the facility as a whole. Where information was available for specific products (e.g., primary packaging) values were assigned directly to that product without allocation. When allocation was required for individual operations within the plant, the milk solids content of the exiting streams was used as the basis for allocation (Kim et al., 2013; Vergé et al., 2013). Additionally, a scenario analysis was performed to detect the variation in emissions assigned to the main product, using different allocation models at the manufacturing plant.

Figure 2 summarizes the scenario analyses for mozzarella allocation used in our study. Case 1 represents the default allocation model; the inputs were allocated using plant-specific information to assign specific inputs to specific products. Case 2 and Case 3 are presented as scenarios to compare the final results and to test the robustness of Case 1 . Case 2 follows the same process of Case 1, but 4 different allocation models (noallocation, economic, fat, and protein) were applied to the inputs, which were not assigned using plant-specific information. Finally, Case 3 tested 5 allocation models 


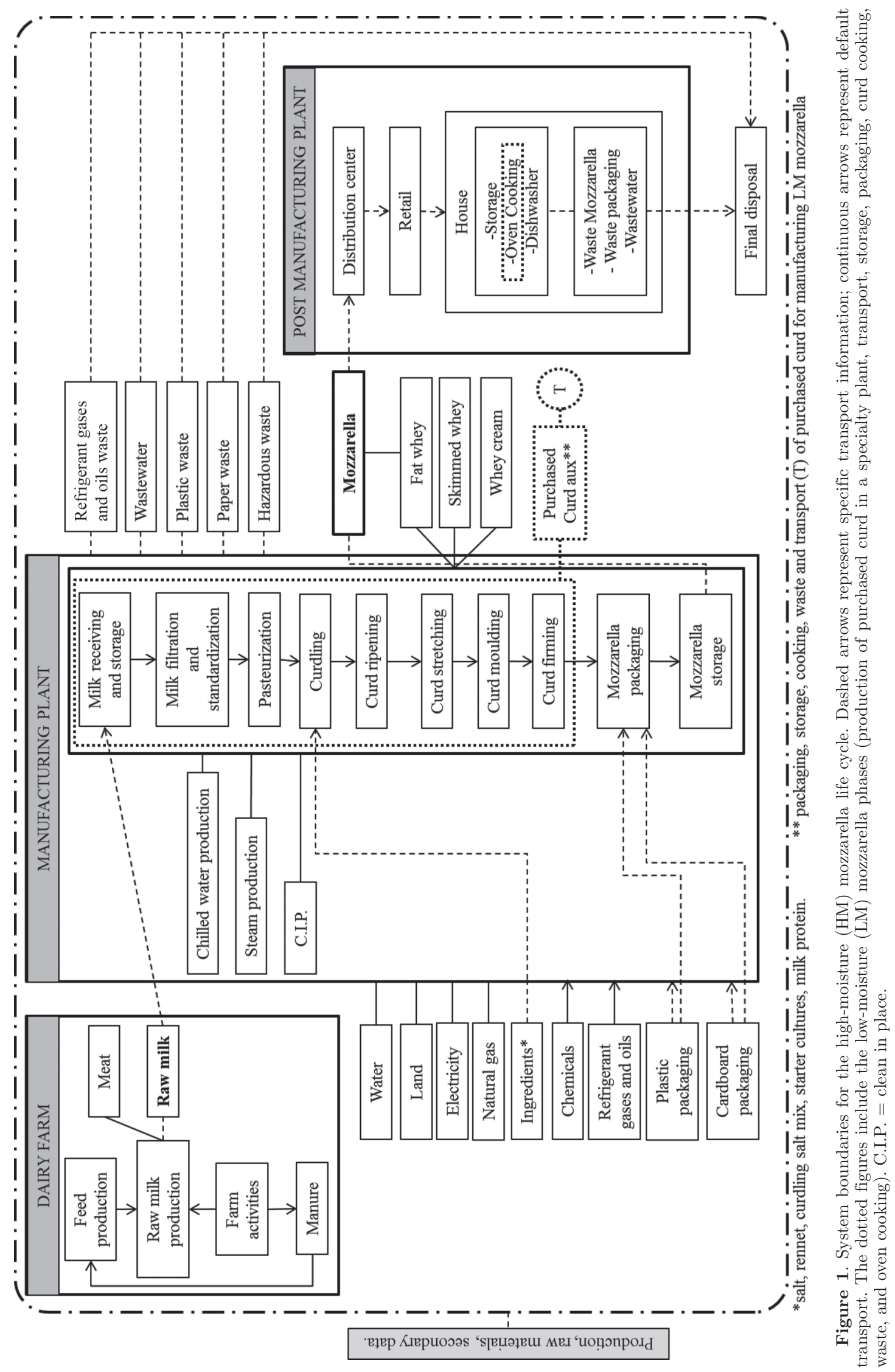




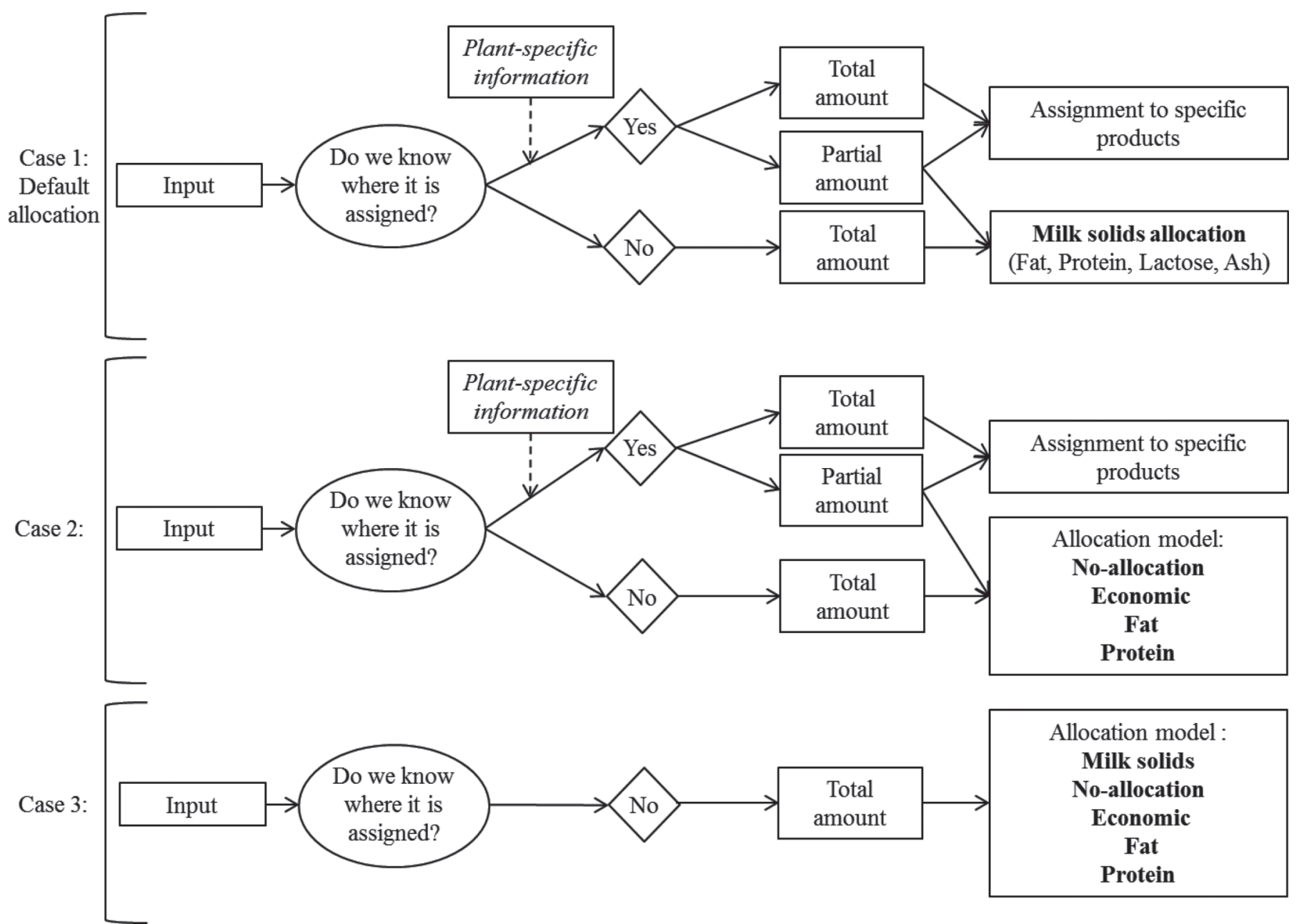

Figure 2. Scenario analysis for allocation models used to allocate resources and emissions between mozzarella and co-products.

(milk solids, no-allocation, economic, fat, and protein), considering a hypothetical situation where no plantspecific information was available to assign the inputs to the specific products, but assuming all input data were at the whole-plant level.

\section{Life Cycle Inventory}

Our study maintained a perspective focused on the mozzarella manufacturing plant. During 2015, the third-largest Italian mozzarella plant was surveyed to collect primary data for the calendar year 2014. The survey included questions regarding resources (materials, energy, water, and land), production (mozzarella and co-products), and waste (liquid and solid). The mozzarella plant used raw milk from both Italian regions and other European states. Notably, a previous study on raw milk production was used as background data for Italian milk (Dalla Riva et al., 2015). The
Ecoinvent v3.2 (Ecoinvent, 2015) was used to identify European raw milk production and secondary data. Uncertainty of inputs was assigned using the Ecoinvent pedigree matrix approach (Weidema et al., 2013), with variability and consistency being checked for primary survey data, whereas the uncertainty distribution provided by Ecoinvent was used unaltered for secondary data. SimaPro 8.1 (PRé Consultants, 2014) was used as the modeling software. Table 1 shows data inventories per kilogram of HM mozzarella before allocation.

HM Mozzarella Manufacturing Plant Data. Surveyed plants produced mozzarella, liquid fat whey, liquid skimmed whey, and whey cream. Data collection was performed on individual operations within the plant to separate the manufacturing process into distinct operations to reduce the need, as much as possible, for allocation of whole-plant data among the multiple products. The plant operations were separated as shown in Figure 3. Specific life cycle inventory unit 
processes were created to represent each operation (i.e., brine production, water purification, steam and chilled water production, and clean-in-place). Loss of milk solids was considered during the manufacture, which was accounted for through collection in the wastewater. The loss was estimated by the difference in milk solids entering the plant with the raw milk and milk solids delivered by the plant with the mozzarella and the coproducts.

Transportation. The study included transport of raw milk from farm to manufacturing plant, transport of mozzarella to distribution and retail centers, as well as transport to consumer's house. Transportation was characterized by the distance driven by refrigerated trucks and the loading of products on the truck. The modeled emission class was EURO 5, with an average 11.8-t transport lorry for Italian transport and a 24.0-t lorry for foreign transport (Ecoinvent, 2015). Transport of other manufacturing inputs was modeled using the specific distance, if information was available; otherwise, in case the transport information was not available or the inputs had multiple origins, the market processes from the Ecoinvent database were used, which included production and transport (Ecoinvent, 2015). Also, transport of raw milk and other inputs were allocated among products using the milk solids default allocation. Post-dairy transport was directly assigned to mozzarella and included a small percentage of transport by ship and by aircraft. Notably, transport of mozzarella from retail to the consumer's house was by passenger

Table 1. Farm gate-to-plant gate life cycle inventory flows per kilogram of high-moisture (HM) mozzarella before allocation, and default allocation model at the manufacturing plant

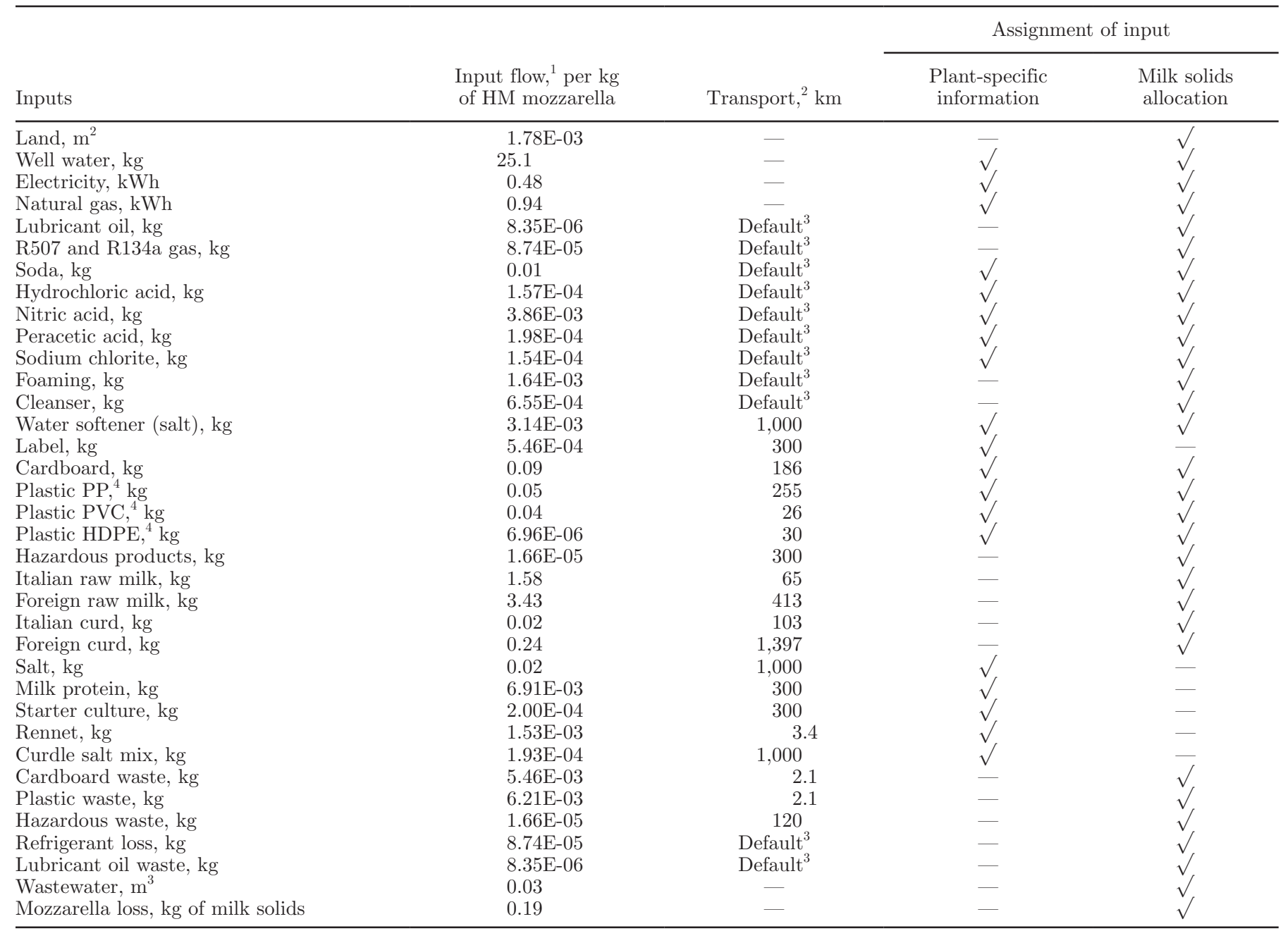

\footnotetext{
${ }^{1}$ The data at whole plant level are divided by total amount of mozzarella.

${ }^{2}$ Transport by EURO 5 truck (Ecoinvent, 2015).

${ }^{3}$ Default transport included in the market processes from Ecoinvent v3.2 database (Ecoinvent, 2015).

${ }^{4} \mathrm{PP}=$ polypropylene; $\mathrm{PVC}=$ polyvinyl chloride; HDPE $=$ high-density polyethylene.
} 
car. The foreign transport of mozzarella from retail to the consumer's house was assumed to be the same as Italian transport due to the low percentage of exported mozzarella (13\% of production) and the limited foreign primary data about that life cycle phase. The average consumer transport distance was assumed to be $10 \mathrm{~km}$ roundtrip. According to Istat (2015a), 1.12\% (mass) of average Italian grocery shopping is composed of dairy products, and $28.6 \%$ of these items are cheese, which includes $37 \%$ of mozzarella (CLAL, 2016), so $0.11 \%$ of the consumer transport impact was attributed to mozzarella, or $0.011 \mathrm{~km} / \mathrm{kg}$ per of mozzarella.

Distribution, Retail, Consumption, Disposal. Data on distribution center, retail, and consumption and disposal phases were derived from the published literature and assumptions, given the limited primary data related to mozzarella production and consumption (Table 2). Of the produced mozzarella, $87 \%$ was sold in Italy and $13 \%$ was exported. An average package of mozzarella has a shelf-life of $30 \mathrm{~d}$. In the present study, we assumed mozzarella was consumed just at the end of the shelf-life period to estimate the greatest impact from storage; obviously if the consumption occurs sooner, the impact will be lower. Generally, mozzarella was stored $1 \mathrm{~d}$ at the dairy plant and then delivered to a distribution center. The distribution, retail, consumption, and disposal phases happening abroad have been assumed the same of the equivalent Italian phases due to the

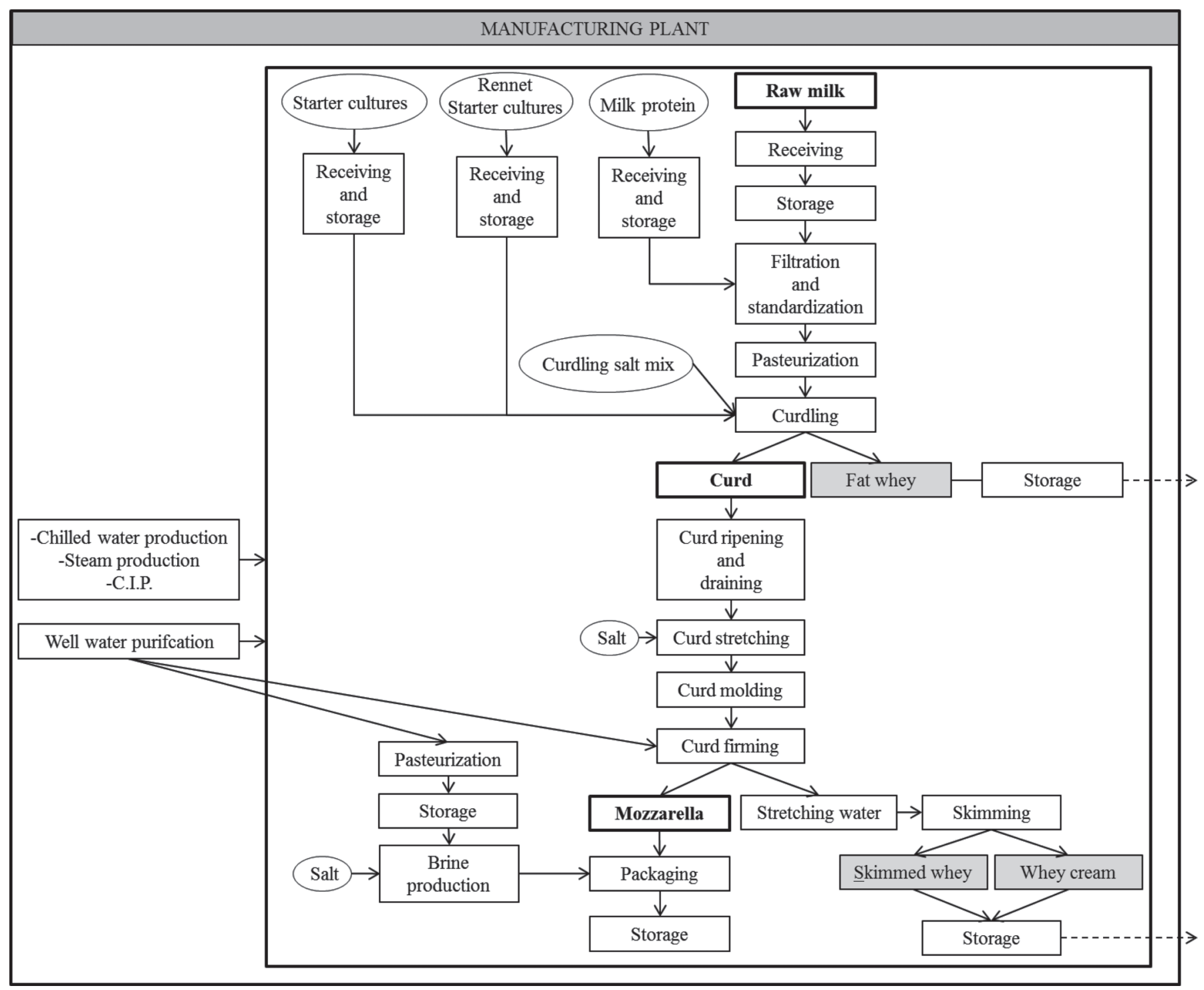

Figure 3. Operations modeled in the manufacturing plant and product outputs along the manufacturing processes for high-moisture (HM) mozzarella (gray rectangles are co-products). C.I.P. = clean in place. 
low percentage of exported mozzarella and the limited foreign primary data about those life cycle phases. Once mozzarella reached the distribution center, it was stored at 2 to $4^{\circ} \mathrm{C}$; the maximum period of storage was $10 \mathrm{~d}$. Importantly, the same storage temperature and duration were considered for retail. According to Flysjö (2011), $0.042 \mathrm{kWh}$ are necessary to store the cheese for $10 \mathrm{~d}$, so $0.0042 \mathrm{kWh} / \mathrm{kg}$ of mozzarella per day were used to model our distribution center and retail processes. To estimate the energy consumption of home refrigeration, an average refrigerator was assumed to have a 200 L capacity and an annual electricity consumption of $320 \mathrm{kWh}$, which equates to $0.0043 \mathrm{kWh} / \mathrm{L}$ per day; with the share of refrigerator occupied by mozzarella being 12.7\% (de Angelis, 2016), $0.00055 \mathrm{kWh}$ are used by home refrigerators per kilogram of mozzarella per day, and mozzarella was stored an average of $5 \mathrm{~d}$ before consumption. A dishwasher was also considered, and according to Kim et al. (2013), $1.51 \mathrm{kWh}$ and $22 \mathrm{~L}$ of water per cycle were used; 5 percent of dishwasher load room was destined per kilogram of mozzarella.

We accounted for mozzarella packaging waste (cardboard boxes and plastic), with recycling, municipal incineration, and landfilling as the waste treatments for cardboard waste and plastic packaging. The percentage of cardboard and plastic waste accumulating in different waste treatments were assumed from ISPRA (2014) for waste treated in Italy; meanwhile data from Plastic Europe (2015) and ERPC (2014) were used for waste treated in other European states. The waste treated in European countries not accounted for in the data was a negligible amount, so it was modeled as European waste. Furthermore, a 50-km transport by truck was assumed to dispose of the waste mozzarella and packaging after the consumption phase, both for Italian and foreign distribution. The dairy plant used a small number of hazardous products (syringes, containers, reagents, and other various materials, mainly derived from routine laboratory analyses on raw milk and mozzarella), which were classified and treated as hazardous waste after use, and this waste was transported $120 \mathrm{~km}$ and disposed in an incineration plant. The plant under study was not equipped to treat wastewater, so the wastewater was modeled as being directly discharged into a municipal treatment system and eventually treated at a municipal wastewater treatment plant. We accounted for mozzarella waste during both distribution and retail phases; primary data were not available, so we considered a mozzarella waste of $2 \%(F A O, 2011)$ for both Italian and foreign phases. However, mozzarella waste at food service establishments and restaurants was not included in the analysis due to lack of available data. According to WRAP (2014), a mozzarella household waste of $9 \%$ was assumed, both for Italian and foreign
Table 2. Plant gate-to-grave life cycle inventory flows per kilogram of high-moisture (HM) mozzarella

\begin{tabular}{|c|c|c|}
\hline Inputs & $\begin{array}{l}\text { Input flow, per } \mathrm{kg} \\
\text { of } \mathrm{HM} \text { mozzarella }\end{array}$ & $\begin{array}{c}\text { Transport, }{ }^{1} \\
\mathrm{~km}\end{array}$ \\
\hline \multicolumn{3}{|l|}{ Distribution } \\
\hline Italian transport, $\mathrm{km}$ & - & 524 \\
\hline Foreign transport, $\mathrm{km}$ & - & 1,092 \\
\hline Foreign airplane transport, $\mathrm{km}$ & - & 8,735 \\
\hline Foreign ship transport, km & - & 17,100 \\
\hline Electricity, kWh & 0.04 & - \\
\hline \multicolumn{3}{|l|}{ Retail } \\
\hline Transport, km & - & 50 \\
\hline Electricity, kWh & 0.09 & - \\
\hline \multicolumn{3}{|l|}{ Consumption } \\
\hline Transport,$^{2} \mathrm{~km}$ & - & 10 \\
\hline Electricity, kWh & 0.1 & - \\
\hline Dishwasher water, $\mathrm{kg}$ & 1.1 & - \\
\hline \multicolumn{3}{|l|}{ Disposal } \\
\hline Waste mozzarella, kg & 0.09 & 50 \\
\hline Paper waste, $\mathrm{kg}$ & 0.11 & 50 \\
\hline Plastic waste, $\mathrm{kg}$ & 0.03 & 50 \\
\hline Wasted brine, $\mathrm{kg}$ & 0.78 & - \\
\hline
\end{tabular}

${ }^{1}$ Transport by EURO 5 truck (Ecoinvent, 2015).

${ }^{2}$ Transport by car.

consumption. The brine included in the package was assumed to be discharged into the kitchen sink and treated as wastewater in a municipal treatment system.

LM Mozzarella (From Purchased Curd). The whole process of the manufacture of HM mozzarella occurred inside 1 dairy plant. The LM mozzarella, however, is manufactured using 2 dairy plants; the curd is manufactured in a specialty plant and transported to a mozzarella manufacturing plant, where it is transformed into mozzarella. Comparatively, LM mozzarella is generally used as an ingredient, such as a pizza topping, so cooking is a required process, whereas mozzarella from raw milk is generally consumed fresh and without cooking. In our study, HM and LM mozzarella were produced in the same dairy plant, and the production lines were completely separate, so it was possible to consider the 2 production lines as 2 separate dairy plants. The plant purchased $92 \%$ of its curd from other European countries, whereas the remaining percentage came from Italian dairy plants. Further, the environmental impacts of LM mozzarella were estimated and then compared with the environmental impacts of HM mozzarella. The comparison between HM and LM mozzarella was shown on the basis of DM content of the products because the comparison is not appropriate for products with different moisture contents when allocation is based on solids content.

The operations from receiving the raw milk to ripening curd during the manufacturing of HM mozzarella were used to model the purchased curd production for LM mozzarella manufacturing, which may have occurred in either Italian or foreign dairy plants before 
Table 3. From farm gate-to-grave, additional input flow per kilogram of low-moisture (LM) mozzarella before allocation

\begin{tabular}{|c|c|c|}
\hline Inputs & $\begin{array}{l}\text { Input flow, per } \mathrm{kg} \\
\text { of LM mozzarella }\end{array}$ & $\begin{array}{c}\text { Transport, }{ }^{1} \\
\mathrm{~km}\end{array}$ \\
\hline \multicolumn{3}{|l|}{ Packaging } \\
\hline Electricity, kWh & $2.85 \mathrm{E}-03$ & - \\
\hline Plastic, kg & $2.04 \mathrm{E}-03$ & Default $^{2}$ \\
\hline \multicolumn{3}{|l|}{ Storage predelivering } \\
\hline Electricity, kWh & 0.02 & - \\
\hline \multicolumn{3}{|l|}{ Delivering to mozzarella plant } \\
\hline Italian transport, $\mathrm{km}$ & - & 103 \\
\hline Foreign transport, km & - & 1,397 \\
\hline \multicolumn{3}{|l|}{ Storage postdelivering } \\
\hline Electricity, kWh & 0.02 & - \\
\hline \multicolumn{3}{|l|}{ Curd cooking } \\
\hline Well water, $\mathrm{kg}$ & 0.23 & - \\
\hline Salt, $\mathrm{kg}$ & 0.01 & 1,000 \\
\hline Natural gas, kWh & 0.12 & - \\
\hline Electricity, kWh & 0.03 & - \\
\hline Mozzarella loss, $\mathrm{kg}$ of milk solids & 0.15 & \\
\hline \multicolumn{3}{|l|}{ Waste } \\
\hline Plastic waste, $\mathrm{kg}$ & $2.04 \mathrm{E}-03$ & 50 \\
\hline \multicolumn{3}{|l|}{ Cooking at consumption } \\
\hline Electricity, kWh & 0.58 & - \\
\hline
\end{tabular}

transport to the manufacturing facility under study. After the ripening and draining, the curd was shaped into blocks, packaged with plastic bags, and refrigerated before delivery. After delivery to the mozzarella plant, the curd was refrigerated for up to $10 \mathrm{~d}$. To produce LM mozzarella, the curd was cut in pieces, warmed with hot water (curd cooking) to soften it, and, finally, stretched and manufactured into mozzarella. Data required for curd production (both domestic and foreign) and the processes following curd ripening and draining (packaging, storage, delivery, and mozzarella production) were taken from data provided for HM mozzarella production. Skimmed whey and whey cream were coproducts of LM mozzarella production, whereas the fat whey was a co-product in the curd manufacturing. The loss of milk solids during LM mozzarella manufacturing (milk solids entering in the plant with the curd minus milk solids delivered by the plant with the mozzarella and the co-products) was included. The same data used for the HM mozzarella post-dairy plant phases were assumed for LM mozzarella; for consumption, however, LM mozzarella was assumed to be a pizza topping and thus required heating and electricity to be cooked in an electric oven [29\% mass allocation factor to mozzarella STG (2016)], obtaining $0.58 \mathrm{kWh} / \mathrm{kg}$ of LM mozzarella from cooking. Waste of LM mozzarella was assumed the same as HM mozzarella; the mozzarella waste at food service establishments and restaurants was not included in the analysis due to the lack of available data, whereas the mozzarella waste at the in-home consumption phase was set at $9 \%$. According to the dairy plant, the shelf-life of LM mozzarella is the same as HM mozzarella. Table 3 shows the additional data inventory per kilogram of LM mozzarella before allocation.

\section{Life Cycle Impact Assessment}

The impact categories were assessed using the ReCiPe midpoint $(\mathrm{H})$ V1.11 framework (Goedkoop et al., 2009). The inventory indicator categories of land occupation and water depletion were also assessed with the ReCiPe framework, and the cumulative energy demand inventory indicator category was assessed by the method of Frischknecht et al. (2007) (Table 4).

\section{RESULTS}

\section{Results of HM Mozzarella}

Figure 4 presents the life cycle impact assessment results from cradle-to-grave and from farm gate-tograve. Table 5 presents the quantitative results for the

Table 4. Inventory and impact categories analyzed in the study and acronyms used in the text ${ }^{1}$

\begin{tabular}{ll}
\hline Life cycle impact category & Life cycle inventory indicator category \\
\hline $\mathrm{CC}=$ climate change, $\mathrm{kg}$ of $\mathrm{CO}_{2}$ equivalents & $\mathrm{CED}=$ cumulative energy demand, MJ \\
$\mathrm{OD}=$ ozone depletion, $\mathrm{kg}$ of $\mathrm{CFC}-11$ equivalents & $\mathrm{LO}=$ land occupation, $\mathrm{m}^{2} \mathrm{a}$ \\
$\mathrm{TA}=$ terrestrial acidification, $\mathrm{kg}$ of $\mathrm{SO}_{2}$ equivalents & $\mathrm{WD}=$ water depletion, $\mathrm{m}^{3}$ \\
$\mathrm{FE}=$ freshwater eutrophication, $\mathrm{kg}$ of $\mathrm{P}$ equivalents & \\
$\mathrm{ME}=$ marine eutrophication, $\mathrm{kg}$ of N equivalents & \\
$\mathrm{HT}=$ human toxicity, $\mathrm{kg}$ of $1,4-\mathrm{DCB}$ equivalents & \\
$\mathrm{ET}=$ ecotoxicity, ${ }^{2} \mathrm{~kg}$ of $1,4-\mathrm{DCB}$ equivalents & \\
$\mathrm{POF}=$ photochemical oxidant formation, $\mathrm{kg}$ of NMVOC & \\
${ }^{1} \mathrm{CFC}=$ chlorofluorocarbon; $1,4-\mathrm{DCB}=1,4$ dichlorobenzene; NMVOC $=$ nonmethane volatile organic com- \\
pound; ${ }^{2}$ a $=$ unit of land occupation is area $\times$ time, in this case square meters of land per year. \\
${ }^{2}$ Ecotoxicity is reported as cumulative of 3 impact categories affecting the environmental sphere: terrestrial, \\
freshwater, and marine ecotoxicity. All 3 impact categories have the same unit of measure, kg of $1,4-\mathrm{DCB}$ \\
equivalents, according to Goedkoop et al. (2009). Whereas, human ecotoxicity was considered by itself due to \\
its repercussion on human health.
\end{tabular}




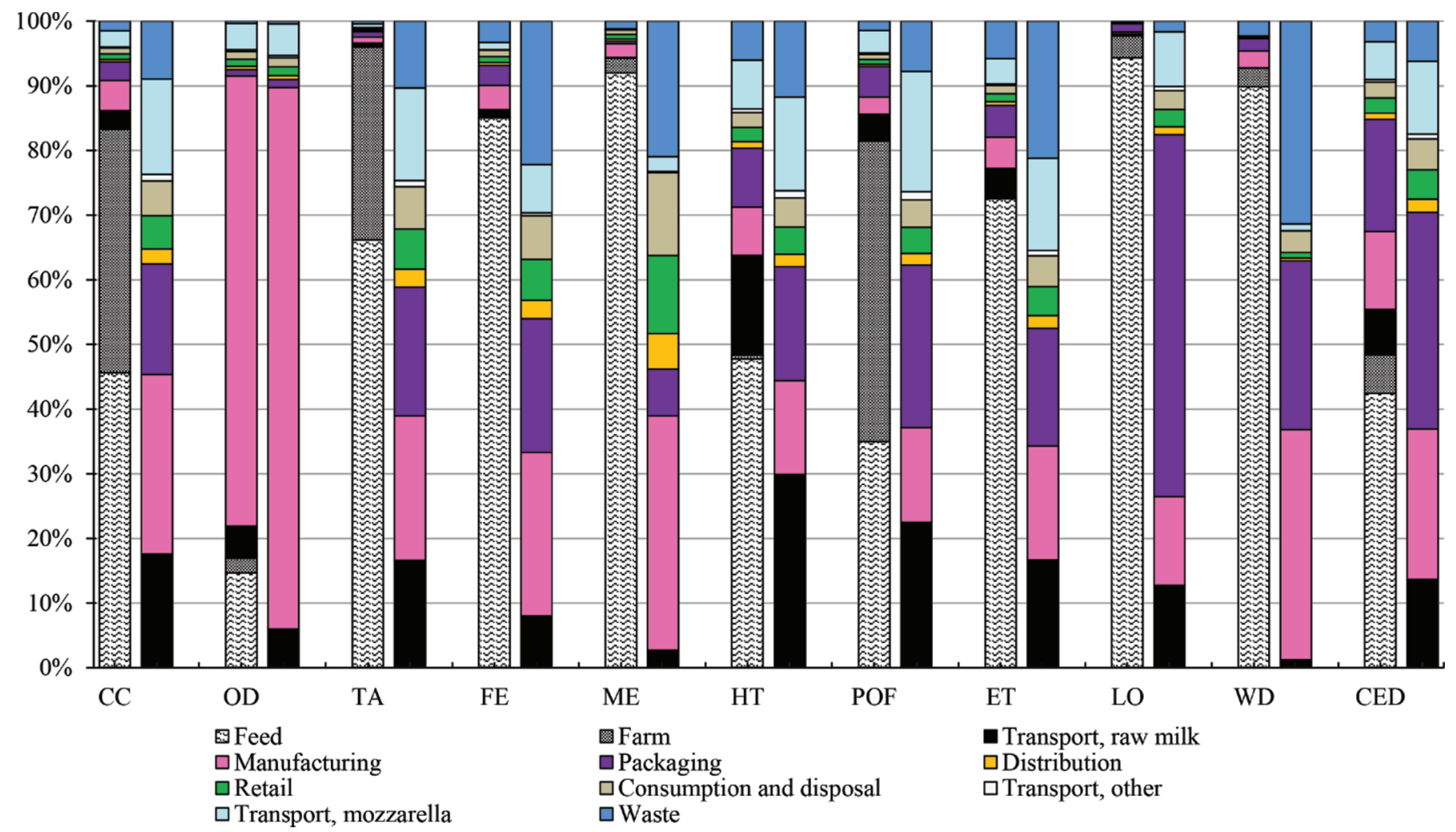

Figure 4. Life cycle impact assessment results for the supply chain of high-moisture (HM) mozzarella: cradle-to-grave (left column) and farm gate-to-grave (right column) perspectives. $\mathrm{CC}=$ climate change; $\mathrm{OD}=$ ozone depletion; $\mathrm{TA}=$ terrestrial acidification; $\mathrm{FE}=$ freshwater eutrophication; $\mathrm{ME}=$ marine eutrophication; $\mathrm{HT}=$ human toxicity; $\mathrm{POF}=$ photochemical oxidant formation; $\mathrm{ET}=\mathrm{ecotoxicity} ; \mathrm{LO}=$ land occupation; $\mathrm{WD}=$ water depletion; $\mathrm{CED}=$ cumulative energy demand. Color version available online.

full supply chain of HM mozzarella consumption. Raw milk production contributed the largest effects for most impact categories. Feed production was the main contributor at the farm phase for all impact categories, and farm activities were relevant in climate change (CC), terrestrial acidification, and photochemical oxidant formation (POF). Ozone depletion (OD), human toxicity $(\mathbf{H T})$, and cumulative energy demand (CED) were the only 3 categories where post-farm gate activities contributed more than $50 \%$ of the final impact; OD was mainly determined by manufacturing operations, HT was mainly related to transport activities, and CED was determined by energy usage, packaging, and transport activities. Furthermore, manufacturing and packaging had the largest contribution in the post-farm supply chain, except for HT, POF and ME. Indeed, more than $40 \%$ of post-farm gate HT and POF was caused from raw milk transport and transport of mozzarella, whereas the same percentage for marine eutrophication ( $\mathbf{M E}$ ) was derived from retail, consumption, and waste, which signals an important contribution along the post-farm chain. Energy production and utilization were the main drivers in several impact categories, primarily for CC and $\mathrm{CED}$, whereas the production and use of packaging contributed to land occupation (LO), CED, and water depletion (WD).

Manufacturing and packaging are directly controlled by the mozzarella manufacturer, and given their relatively large contribution to final effects after the farm gate, it is reasonable to analyze gate-to-gate impacts and contribution for the dairy plant (Figure 5). Electricity, natural gas, and secondary packaging (cardboard boxes) were the main drivers from mozzarella manufacturing, excluding OD and WD. Refrigerant losses were the main contributors to OD, with its largest contribution after the farm gate related to storage and transport of mozzarella, whereas wastewater treatment and well water for processes were main contributors for WD. Land occupation was mainly determined by secondary cardboard packaging; that is, the boxes that transport the packaged mozzarella to a distribution center and then to retail. This result was somewhat unanticipated, 


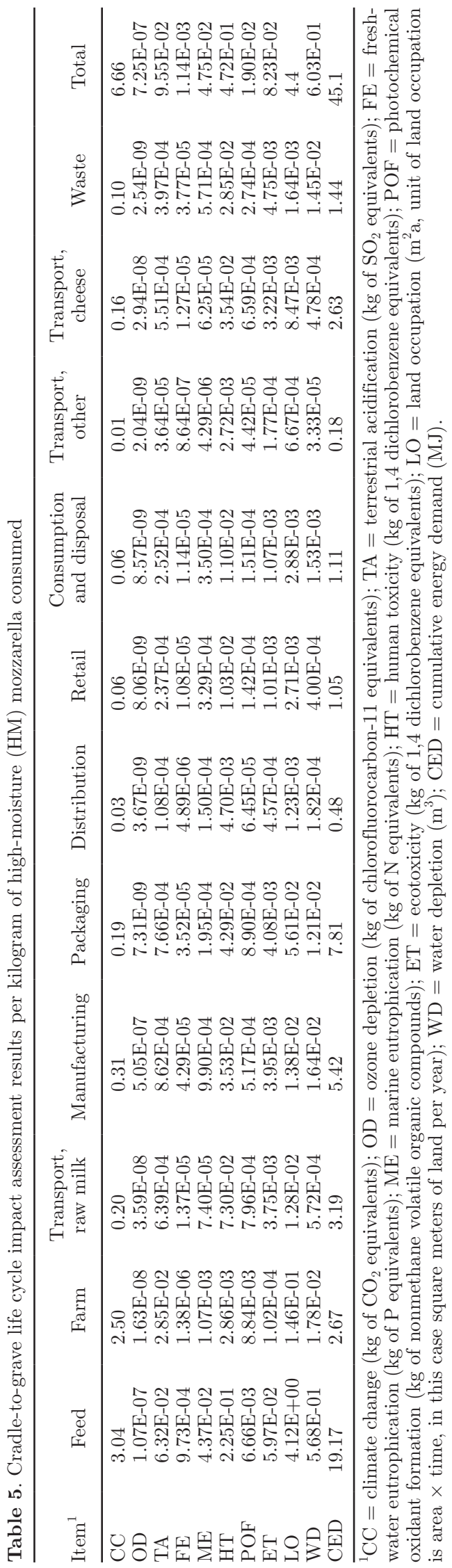

as the delivery of packaged mozzarella required a large number of cardboard boxes, so the cardboard box usage had repercussions on environmental impacts. Notably, wastewater particularly affected WD, ME, freshwater eutrophication (FE), and ecotoxicity (ET). Nitrogen and phosphate in wastewater were a significant source of eutrophication, both for FE and ME. Finally, the post-dairy plant phases were mainly driven by electricity usage for cooling and storage of mozzarella and secondarily by transport, whereas wastewater produced during mozzarella consumption, including the brine used to preserve the freshness of mozzarella, were relevant for $\mathrm{WD}, \mathrm{FE}$, and $\mathrm{ME}$ in the post-dairy plant analysis.

\section{Normalization}

Normalization is useful to identify the impact categories, which are important for this specific sector (Kim et al., 2013). ReCiPe Midpoint (H) V1.11 European normalization factors (Goedkoop et al., 2009) were used to normalize emissions from the Italian annual per capita HM mozzarella consumption, determined by the total Italian annual mozzarella consumption (280,643,295 $\mathrm{kg}$; Assolatte, 2015) divided by the Italian population $(60,795,612$ citizens; Istat, 2015b). Normalized results represent the fractional contribution of mozzarella consumption by Italians, to an average European Union citizen's cumulative annual environmental impact. Normalization results are shown in Figure 6. Ecotoxicity represented $4.2 \%$ of the annual ecotoxicity impact, whereas $\mathrm{ME}$ was $2.2 \%$ of the annual marine eutrophication impact. Both ET and ME were derived mainly from feed production at farm, waste treatment, and transport activities along the supply chain. Meanwhile the third and fourth largest impact categories (both $1.3 \%$ ) were the terrestrial acidification and FE, mostly originating from the use of phosphorus fertilizer. Applying normalization in a farm gate-to-grave perspective shows that the ET, FE, and HT still occupied the first positions with regard to contribution to impacts, whereas ME was third. These results were all mainly driven by transport activities, waste treatment, and electricity usage.

\section{Uncertainty Analysis}

The LCA results for $1 \mathrm{~kg}$ of HM mozzarella consumed were analyzed using 1,000 Monte Carlo simulation runs (Table 6). Ecoinvent v3 pedigree matrix (Weidema et al., 2013) was used to assign the quality of individual data; CC, CED, and WD were relevant impact categories for dairy production. The $95 \%$ confidence interval was 5.86 to $7.93 \mathrm{~kg}$ of $\mathrm{CO}_{2}$ equivalents and 38.6 to 


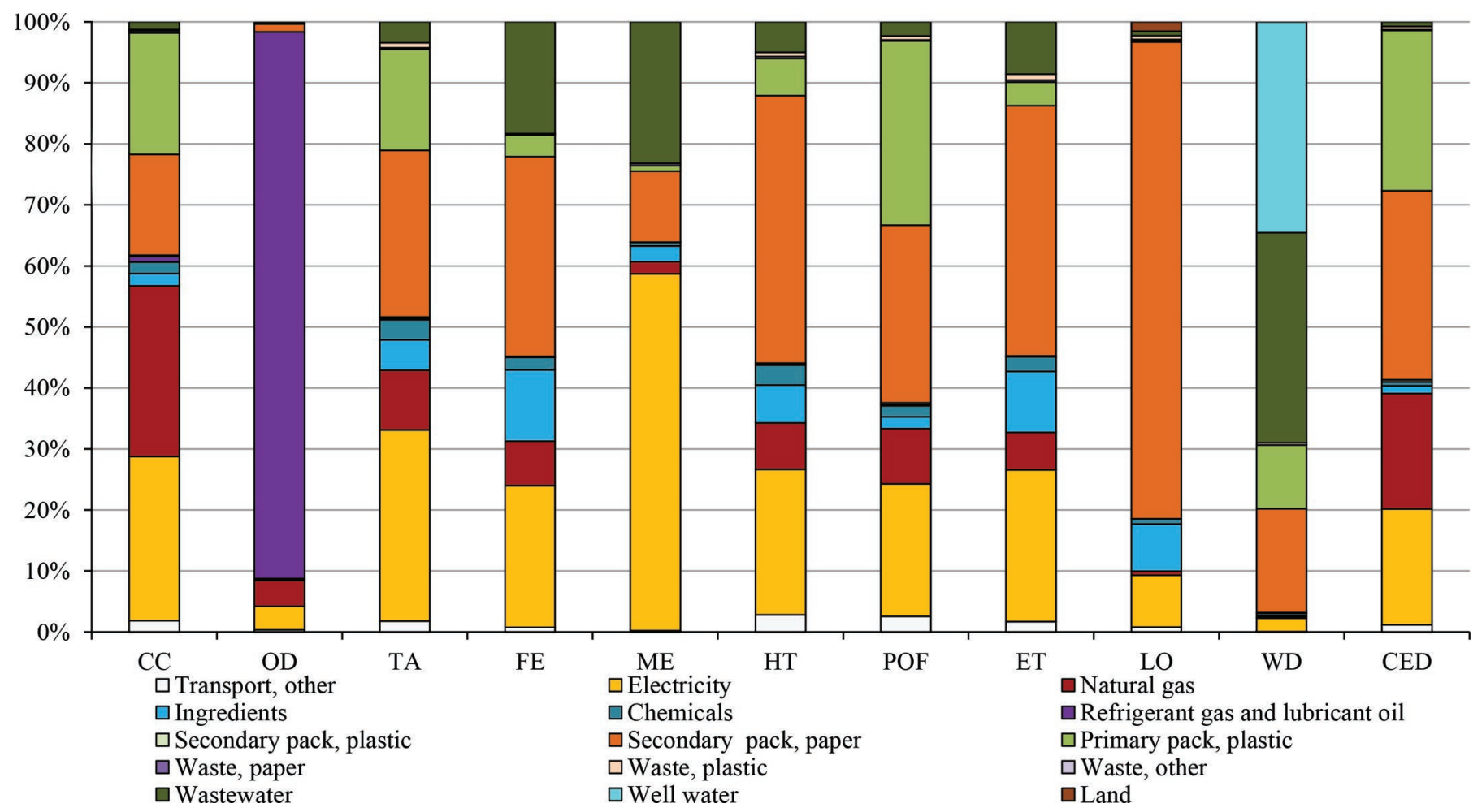

Figure 5. Contribution to environmental impacts from gate-to-gate at manufacturing plant of high-moisture $(\mathrm{HM})$ mozzarella. CC $=$ climate change; $\mathrm{OD}=$ ozone depletion; $\mathrm{TA}=$ terrestrial acidification; $\mathrm{FE}=$ freshwater eutrophication; $\mathrm{ME}=$ marine eutrophication; HT $=$ human toxicity; $\mathrm{POF}=$ photochemical oxidant formation; $\mathrm{ET}=$ ecotoxicity; $\mathrm{LO}=$ land occupation; $\mathrm{WD}=$ water depletion; CED = cumulative energy demand. Color version available online.

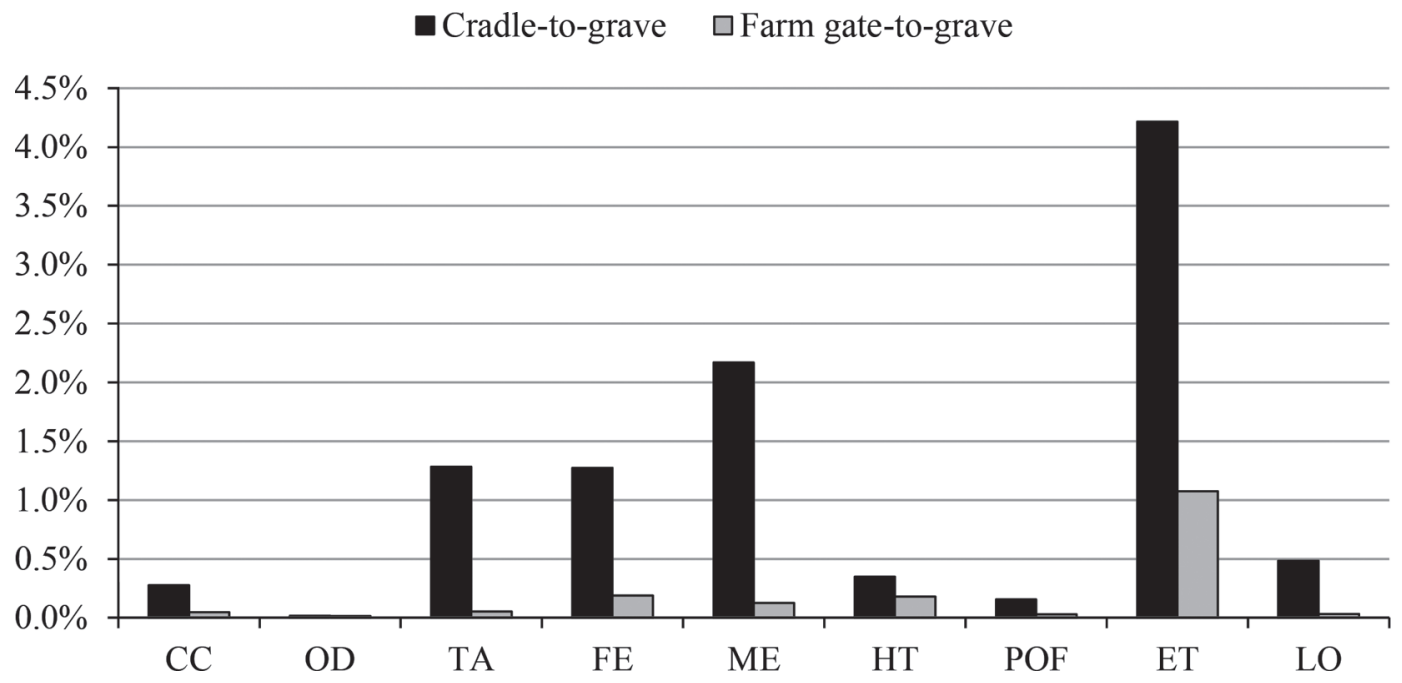

Figure 6. Normalization of cradle-to-grave (black bar) and farm gate-to-grave (gray bar) effects for $4.6 \mathrm{~kg}$ of high-moisture (HM) mozzarella consumed. $\mathrm{CC}=$ climate change; $\mathrm{OD}=$ ozone depletion; $\mathrm{TA}=$ terrestrial acidification; $\mathrm{FE}=$ freshwater eutrophication; $\mathrm{ME}=$ marine eutrophication; HT = human toxicity; POF = photochemical oxidant formation; ET = ecotoxicity; LO = land occupation. 
Table 6. Uncertainty analysis using 1,000 Monte Carlo simulation runs of $1 \mathrm{~kg}$ of high-moisture (HM) mozzarella consumed from cradle-to-grave

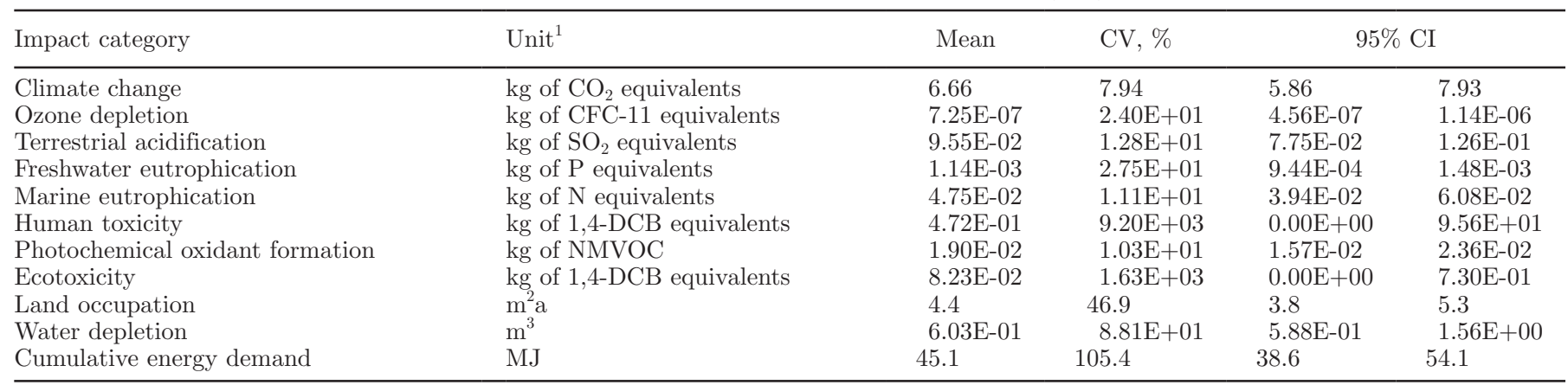

$\overline{{ }^{1} \mathrm{CFC}}=$ chlorofluorocarbon; $1,4-\mathrm{DCB}=1,4$ dichlorobenzene; NMVOC $=$ nonmethane volatile organic compound; $\mathrm{m}^{2} \mathrm{a}=$ unit of land occupation is area $\times$ time, in this case square meters of land per year.

54.1 MJ for CC and CED per kilogram of mozzarella consumed, respectively. The average emissions were $6.66 \mathrm{~kg}$ of $\mathrm{CO}_{2}$ equivalents and 45.1 MJ of cumulative energy demand $/ \mathrm{kg}$ of mozzarella consumed. Both CC and CED were derived at 14 and $45 \%$ from the dairy plant to grave perspective, respectively; whereas 0.94 $\mathrm{kg}$ of $\mathrm{CO}_{2}$ equivalents and $20.3 \mathrm{MJ}$ were the impacts per kilogram of mozzarella at the dairy plant. The water depletion per kilogram of mozzarella consumed was $0.60 \mathrm{~m}^{3}$, whereas the water depletion from the dairy farm gate-to-grave perspective was $3 \%$ of the total WD, equivalent to $18 \mathrm{~L} / \mathrm{kg}$ of mozzarella consumed; $80 \%$ of this water was used during mozzarella manufacturing in the dairy plant.

\section{DISCUSSION}

Our study is an analysis from cradle-to-grave of mozzarella consumption. In line with published literature of LCA of dairy production (Kim et al., 2013; Vergé et al., 2013; Broekema and Kramer, 2014; Palmieri et al., 2016), most of the effects were related to raw milk production; therefore, immediate suggestions for impact improvement are related to dairy farm activities. Farm effects related to feed production (fertilization, transport, processing, and land and water use) and animals (enteric methane, nitrous oxide, and methane from manure management) are the hotspots for improvements, as stated previously by Berlin (2002), Rotz et al. (2010), Kim et al. (2013), Thoma et al. (2013), Vergé et al. (2013), and Palmieri et al. (2016).

The normalization suggests that ET and ME are the main impact categories where environmental mitigations should be focused, as the relative contribution of mozzarella production and consumption was larger than other impact categories. The ME was closely related to nitrogen, which was released in water after nitrogen fertilizer application during feed production.
The ET was derived mainly from feed used at the farm phase, mainly from production and use of purchased feed, both for Italian and foreign raw milk production. In particular, soybean and corn, used as main ingredients in concentrate feed for lactating cows, represented more than $80 \%$ of the purchased feed-related ET. After the purchased feed contribution, ET was determined by on-farm feed production, primarily corn silage for Italian milk and grass silage for foreign milk. Pesticides (mainly for purchased feed production), heavy metals (contained in fertilizers), and transport of off-farm inputs and fields operation, in order, were the main contributing substances and activities to ET associated with feed; similar to the results reported by Eide (2002) and Ledgard et al. (2016). Considering the post-farm phases, fossil fuels used for electricity production and mozzarella transport were the primary contributors to ET. Moreover, considerable ET was associated with waste management, particularly from heavy metals released by landfilling; again, in line with Eide (2002). Therefore, efforts to reduce electricity and fuel consumption in post-farm mozzarella life cycle will lead to broad impact reduction, as suggested by Kim et al. (2013).

Water use is an important aspect of dairy production (Ridoutt et al., 2010). In our study, more than $90 \%$ of WD arose from feed production and farm activities. Notably it is interesting to analyze water use using the recent method AWARE (Available WAter REmaining) v1.02, which is a recommended method from the WULCA (Water Use in LCA) Group to assess water scarcity impact in LCA, the method is also endorsed by the EU Joint Research Center (WULCA, 2017). A full comparison between the method to assess the WD in our study (Goedkoop et al., 2009) and the full implementation of the AWARE method is complex and falls outside of the current study's goal; moreover, the software SimaPro 8.1 (PRé Consultants, 2014) has a 
limited implementation of the AWARE method. However, we consider that the application of the AWARE method increases the value of our analysis and is a starting point for future research. The application of the AWARE method was performed considering all the mozzarella life cycle phases used in the current study. Considering the cradle-to-grave perspective, the AWARE method identified $1.58 \mathrm{~m}^{3}$ of water scarcity per kilogram of mozzarella consumed. In contrast to the baseline method, the AWARE result shows that packaging (mainly cardboard boxes used during mozzarella transport) was the main driver (54\%), followed by feed production for animals (20\%), farm activities $(13 \%)$, and mozzarella manufacturing (6\%). Distribution, retail, and consumption contributed $4 \%$ of impact, and waste and transport (mainly milk and mozzarella) caused 1 and $2 \%$ of water scarcity, respectively. Feed production for animals was the main driver of water scarcity for both Italian and foreign raw milk. Purchased feed, mainly protein feed (such as soybean) was the main contributor $(70 \%)$ to water scarcity in the feed production phase, whereas fertilizer production, irrigation, and energy used in the feed mill were the main processes consuming water; secondarily, water scarcity occurred from on-farm feed production $(25 \%)$ of corn silage for Italian milk and grass silage for foreign milk. Finally, drinking water for animals and a minor contribution from energy usage were the main drivers at the farm phase $(5 \%)$.

Importantly, manufacturing was the phase of the mozzarella life cycle mainly analyzed in our study. We evaluated 1 mozzarella plant, yet we considered the model to be a suitable representation of the Italian mozzarella production, excluding special mozzarella production such as aged or smoked mozzarella, due to the limited production level and the artisanal rather than industrialized production technology. Manufacturing operations were the main contributors for OD, whereas transport of raw milk and mozzarella were important contributors for HT and ET, from the post-farm gate perspective, as also reported by Kim et al. (2013). This situation is different than reported by Palmieri et al. (2016), where negligible effects of transport activities (mainly raw milk) were found due to the short distance between farm and factory. Comparatively, in our study, $68 \%$ of the raw milk was imported from other European countries, increasing the distance from the farm to the mozzarella facility. Further, whereas $87 \%$ of mozzarella had a national market, the remainder was internationally distributed $(1,561 \mathrm{~km})$.

Climate change and CED were mainly determined by energy usage, where mozzarella-making and packaging production were the 2 main energy-consuming phases in the post-farm gate supply chain, and energy was primarily linked to electricity usage. Effects of energy usage, its linkage with electricity, and its relevance after farm gate were determined by several authors (Guinard et al., 2009; Kim et al., 2013; Vergé et al., 2013; Palmieri et al., 2016). Moreover, the effects of packaging were relevant, in agreement with EPD (2013), where mozzarella packaging was a main driver after farm and manufacturing phases for resource depletion, photochemical oxidant formation, acidification, and eutrophication. The same impacts were derived from packaging in our study and in the study of Sonesson and Berlin (2003); whereas González-García et al. (2013a) and Broekema and Kramer (2014) estimated low impacts from packaging, and its contribution is mainly present for land occupation. In our study, land occupation and CED were mainly caused by cardboard packaging; in fact, land was occupied for many years (up to $30 \mathrm{yr}$ ) to grow trees for cardboard-making, and electricity was used to process both cardboard and plastic packaging.

Large amounts of small cardboard box packaging were used to deliver the mozzarella; this can be considered as an inefficiency in the use of packaging because small amounts of mozzarella were packaged in each box, whereas a large packaging would use less packaging per unit volume of mozzarella and lead to impact reduction (Marsh and Bugusu, 2007). Nevertheless, it is important to take into consideration the type of mozzarella market, which is characterized by a wide network of small Italian and foreign retailers. These retailers are supplied with the most common packaged shape (HM mozzarella balls, $0.125 \mathrm{~kg}$, packaged using a plastic film); therefore, a small quantity of mozzarella delivered using small cardboard boxes is better managed by the retailers, although this leads to increase of packaging use and, in turn, impacts. At the manufacturing plant, wastewater treatment together with energy and packaging usage presented a considerable driver to WD, FE, ME and ET, as reported by Kim et al. (2013), Broekema and Kramer (2014) and Palmieri et al. (2016). Phosphate, nitrogen, and chemical oxygen demand contained in the wastewater were the key substances contributing to freshwater and marine eutrophication and ecotoxicity, in line with GonzálezGarcía et al. (2013b).

Another suggestion is that the manufacturing phase could be targeted for emission improvements. Cheese manufacturing and cheese distribution by trucks consumes a lot of energy; thus, a reduction of energy consumption, an increase in renewable source fuels and energy, and an emissions reduction for trucks could improve the environmental profile of mozzarella (González-García et al., 2013a). Additionally, packag- 
ing is one of the main contributors for several categories in that packaging presents a wide variation of impact contribution based on its type, especially for dairy products (Foster et al., 2007). Williams and Wikström (2011) studied the relevance of packaging effect of different food items and determined there is a high contribution of packaging for cheese. Those authors found that reduction in packaging for cheese is not always a good solution for impact improvement. In fact, a tradeoff exists between packaging and food waste -insufficient packaging may increase spoilage losses, ultimately leading to greater effects for the supply chain (Marsh and Bugusu, 2007; Williams and Wikström, 2011). Research on food packaging with low environmental burdens suggests biomaterial-based packaging and recycling technology as the most promising options (Chiellini, 2008), together with lightweight packaging (Marsh and Bugusu, 2007). In our case, plastic packaging is fundamental to preserve the freshness and the long shelf-life of mozzarella, whereas the cardboard box packaging was used for delivery and storage. Research on the reduction of packaging amount per kilogram of mozzarella and new eco-sustainable packaging could be a starting point to reduce the impact of packaging in the mozzarella life cycle.

Compared with farm and manufacturing phases, the post-dairy plant and consumption phases played a minor role, as also reported by Broekema and Kramer, (2014) and Palmieri et al. (2016). However, Broekema and Kramer (2014) found that distribution, retail, and consumption contribute mainly to climate change, eutrophication, and energy depletion, which is primarily determined by energy for cooling and lighting. Similarly, in our study, the energy used (mainly electricity) for refrigeration was the main driver at the distribution and consumption phase, which is another key area for reduction and improvement. Finally, our study does not provide information on the co-products' impacts because all of the co-products were sold by the plant and destined for further transformation and utilization, such as animal feed, protein and sugar extraction, and utilization as ingredients for other dairy products. The subsequent use of co-products has been evaluated by several authors as a way to reduce emissions (Flysjo et al., 2014), although in some cases the further processing of co-products can increase the overall emissions, as shown by González-García et al. (2013a), where the drying process of liquid whey from Portuguese cheesemaking increased the total effects at the cheese plant. Notably, a detailed assessment of the potential valorization of co-products is necessary to obtain specific measures of reduction and improvement from this reuse, but this falls outside of our research aims for the current paper.

\section{Allocation Scenario Analysis}

Testing different allocation models is a good way to test the robustness of the results. Table 7 and Figure 7 shows the comparison between the default allocation (Case 1) and the 2 allocation scenario analyses (Case 2 and Case 3). Moving from milk solids allocation through protein and fat allocation, as well as economic allocation and no-allocation, the CC and CED ranged from 6 to $13 \mathrm{~kg}$ of $\mathrm{CO}_{2}$ equivalents and from 37 to $80 \mathrm{MJ}$ of cumulative energy demand $/ \mathrm{kg}$ of mozzarella consumed, respectively. Comparing the 2 scenario analyses, Case 3 assigned lower emissions than Case 2 to overall impacts, except when no-allocation was applied. The lower values of Case 3 suggest that assuming the data at the whole-plant level, without plant-specific information, determines a lower assignment (i.e., a lower allocation factor) of resources to mozzarella than Case 2. This observation suggests that Case 2 better represents the resource assignments inside the dairy plant because these assignments represent the main aim of dairy plant, which is mozzarella production. Moreover, the ISO requirement (ISO 2006a,b) suggests resource attribution to plant operations and products, using specific plant information as a means of system separation to avoid allocation. The results show the no-allocation model is the best model to evaluate the impacts at the whole-plant level, without considering co-products and their further processes, which indicates better strategies for reduction at the plant to the manufacturers. Meanwhile, the milk solids allocation may be more appropriate to follow the resource flows inside the plant and their assignments to each product. The economic model remains one of the most-used models for allocation (FAO, 2016), which clearly reflects the first aim of the manufacturers, although it does not necessarily reflect the material and energy flows of the production system (Ayer et al., 2007).

\section{Impacts of LM Mozzarella}

Mozzarella from purchased curd (LM) had larger impacts than mozzarella produced directly from raw milk (HM). This finding was anticipated, as adding phases to the life cycle will increase environmental burdens. To compare the 2 types of mozzarella, it is important to note 2 facts. First, HM and LM mozzarella are 2 different products, having different moisture contents; therefore, a direct comparison considering the kilograms of mozzarella consumed is not appropriate. Second, the 2 mozzarella processes result in different allocation factors at the manufacturing plant due to different moisture contents and different amounts of co-products. For these reasons, we present the com- 
Table 7. Impact results per kilogram of high-moisture (HM) mozzarella consumed with allocation scenario analyses $(\text { Case } 2 \text { and Case } 3)^{1}$

\begin{tabular}{|c|c|c|c|c|c|c|c|c|c|c|}
\hline Impact & $\begin{array}{c}\text { Case } 1^{2} \\
\text { Milk } \\
\text { solids }\end{array}$ & \multicolumn{4}{|c|}{ Case $2^{3}$} & \multicolumn{5}{|c|}{ Case $3^{4}$} \\
\hline OD & $7.25 \mathrm{E}-07$ & $1.24 \mathrm{E}-06$ & $1.18 \mathrm{E}-06$ & $9.94 \mathrm{E}-07$ & $9.75 \mathrm{E}-07$ & $7.80 \mathrm{E}-07$ & $1.67 \mathrm{E}-06$ & $1.20 \mathrm{E}-06$ & $1.05 \mathrm{E}-06$ & $1.01 \mathrm{E}-06$ \\
\hline TA & $9.55 \mathrm{E}-02$ & $1.68 \mathrm{E}-01$ & $1.60 \mathrm{E}-01$ & $1.33 \mathrm{E}-01$ & $1.31 \mathrm{E}-01$ & $9.40 \mathrm{E}-02$ & $2.01 \mathrm{E}-01$ & $1.59 \mathrm{E}-01$ & $1.32 \mathrm{E}-01$ & $1.29 \mathrm{E}-01$ \\
\hline $\mathrm{FE}$ & $1.14 \mathrm{E}-03$ & $1.95 \mathrm{E}-03$ & $1.87 \mathrm{E}-03$ & $1.57 \mathrm{E}-03$ & $1.54 \mathrm{E}-03$ & $1.07 \mathrm{E}-03$ & $2.28 \mathrm{E}-03$ & $1.79 \mathrm{E}-03$ & $1.49 \mathrm{E}-03$ & $1.46 \mathrm{E}-03$ \\
\hline $\mathrm{POF}$ & $1.90 \mathrm{E}-02$ & $3.22 \mathrm{E}-02$ & 3.09E-02 & $2.60 \mathrm{E}-02$ & $2.55 \mathrm{E}-02$ & 1.77E-02 & $3.78 \mathrm{E}-02$ & $2.97 \mathrm{E}-02$ & $2.48 \mathrm{E}-02$ & $2.43 \mathrm{E}-02$ \\
\hline ET & $8.23 \mathrm{E}-02$ & $1.35 \mathrm{E}-01$ & $1.30 \mathrm{E}-01$ & $1.10 \mathrm{E}-01$ & $1.08 \mathrm{E}-01$ & 7.20E-02 & $1.54 \mathrm{E}-01$ & $1.20 \mathrm{E}-01$ & $1.01 \mathrm{E}-01$ & $9.83 \mathrm{E}-02$ \\
\hline LO & 4.4 & 7.7 & 7.4 & 6.1 & 6 & 4.3 & 9.2 & 7.3 & 6.1 & 6 \\
\hline WD & $6.03 \mathrm{E}-01$ & $1.06 \mathrm{E}+00$ & $1.01 \mathrm{E}+00$ & $8.43 \mathrm{E}-01$ & $8.26 \mathrm{E}-01$ & $5.97 \mathrm{E}-01$ & $1.28 \mathrm{E}+00$ & $1.01 \mathrm{E}+00$ & $8.39 \mathrm{E}-01$ & $8.21 \mathrm{E}-01$ \\
\hline CED & 45.1 & 69.6 & 67.1 & 58 & 57 & 37.3 & 79.6 & 60.7 & 51.6 & 50.1 \\
\hline
\end{tabular}

${ }^{1} \mathrm{CC}=$ climate change $\left(\mathrm{kg}\right.$ of $\mathrm{CO}_{2}$ equivalents); $\mathrm{OD}=$ ozone depletion ( $\mathrm{kg}$ of chlorofluorocarbon -11 equivalents); TA = terrestrial acidification ( $\mathrm{kg}$ of $\mathrm{SO}_{2}$ equivalents); $\mathrm{FE}=$ freshwater eutrophication ( $\mathrm{kg}$ of P equivalents); $\mathrm{ME}=$ marine eutrophication $(\mathrm{kg}$ of $\mathrm{N}$ equivalents); HT $=$ human toxicity ( $\mathrm{kg}$ of 1,4 dichlorobenzene equivalents); $\mathrm{POF}=$ photochemical oxidant formation $(\mathrm{kg}$ of nonmethane volatile organic compounds); ET $=$ ecotoxicity ( $\mathrm{kg} \mathrm{1,4}$ dichlorobenzene equivalents); $\mathrm{LO}=$ land occupation $\left(\mathrm{m}^{2} \mathrm{a}\right.$, unit of land occupation is area $\times$ time, in this case square meters of land per year); $\mathrm{WD}=$ water depletion $\left(\mathrm{m}^{3}\right) ; \mathrm{CED}=$ cumulative energy demand $(\mathrm{MJ})$.

${ }^{2}$ Default allocation model: plant-specific information and milk solids allocation.

${ }^{3}$ Allocation scenario analysis: plant-specific information and no allocation, economic, fat, protein allocations.

${ }^{4}$ Allocation scenario analysis: inputs data at whole plant level allocated using milk solids, no allocation, economic, fat, protein allocations.

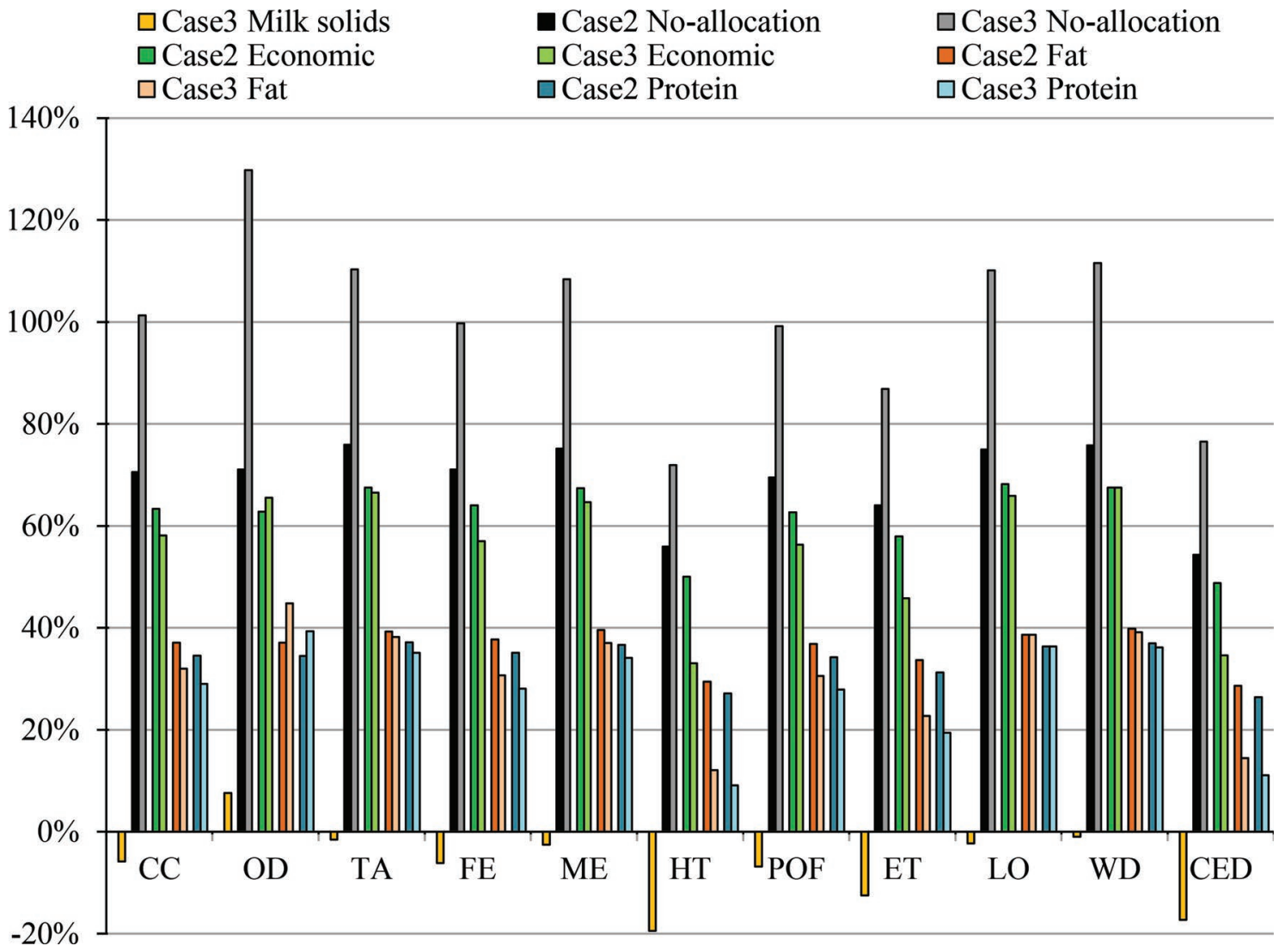

Figure 7. Percent variation of allocation scenario analyses Case 2 (plant-specific information and un-allocation, economic, fat, protein allocations) and Case 3 (inputs data at the whole-plant level allocated using milk solids, un-allocation, economic, fat, protein allocations) with respect to Case 1 (0\%; plant-specific information and milk solids allocation) in high-moisture (HM) consumption. CC $=$ climate change; OD $=$ ozone depletion; $\mathrm{TA}=$ terrestrial acidification; $\mathrm{FE}=$ freshwater eutrophication; $\mathrm{ME}=$ marine eutrophication; $\mathrm{HT}=$ human toxicity; $\mathrm{POF}=$ photochemical oxidant formation; $\mathrm{ET}=$ ecotoxicity; $\mathrm{LO}=$ land occupation; $\mathrm{WD}=$ water depletion; $\mathrm{CED}=$ cumulative energy demand. Color version available online. 
Table 8. Environmental impacts (dry basis) of high-moisture (HM) and low-moisture (LM) mozzarella from farm gate-to-grave and source of variation of LM mozzarella before allocation

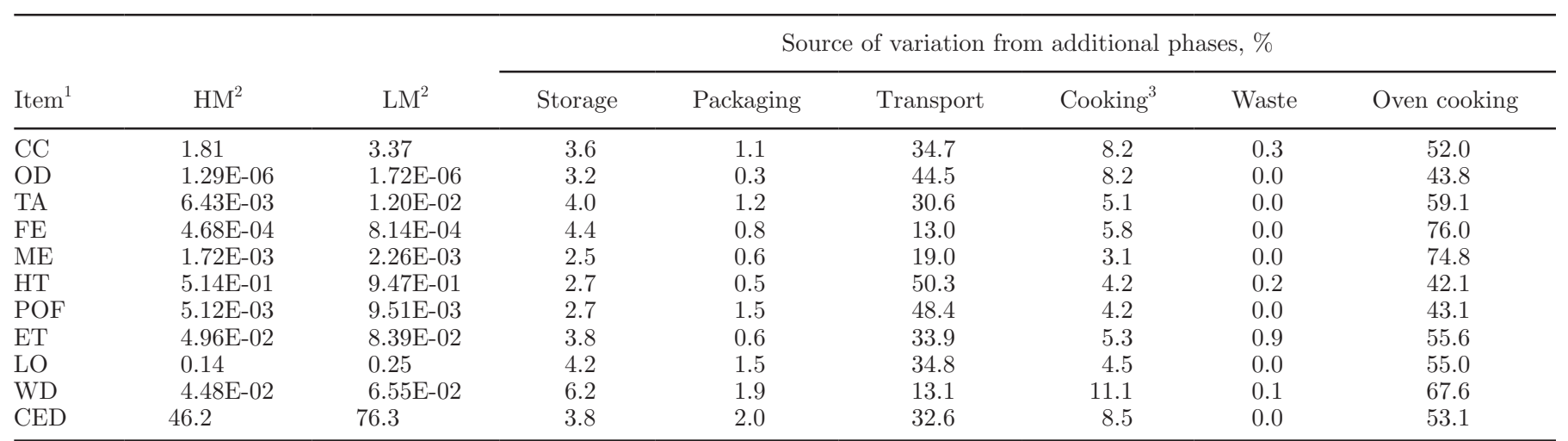

${ }^{1} \mathrm{CC}=$ climate change $\left(\mathrm{kg}\right.$ of $\mathrm{CO}_{2}$ equivalents $) ; \mathrm{OD}=$ ozone depletion ( $\mathrm{kg}$ of chlorofluorocarbon -11 equivalents); TA = terrestrial acidification ( $\mathrm{kg}$ of $\mathrm{SO}_{2}$ equivalents); $\mathrm{FE}=$ freshwater eutrophication ( $\mathrm{kg}$ of $\mathrm{P}$ equivalents); $\mathrm{ME}=$ marine eutrophication $(\mathrm{kg}$ of $\mathrm{N}$ equivalents); HT = human toxicity ( $\mathrm{kg}$ of 1,4 dichlorobenzene equivalents); $\mathrm{POF}=$ photochemical oxidant formation $(\mathrm{kg}$ of nonmethane volatile organic compounds); ET $=$ ecotoxicity ( $\mathrm{kg} 1,4$ dichlorobenzene equivalents); $\mathrm{LO}=$ land occupation $\left(\mathrm{m}^{2} \mathrm{a}\right.$, unit of land occupation is area $\times$ time, in this case square meters of land per year); $\mathrm{WD}=$ water depletion $\left(\mathrm{m}^{3}\right) ; \mathrm{CED}=$ cumulative energy demand $(\mathrm{MJ})$.

${ }^{2}$ The results are expressed as DM.

${ }^{3}$ Curd warming before LM mozzarella making.

parison of the 2 mozzarella on a dry basis. In this case, the comparison between the 2 types of mozzarella were made without the use of allocation, to better represent the phases and operations determining differences of LM mozzarella with respect to HM mozzarella, as well as to remove bias from the allocation results. Importantly, the impacts are overstated because no impacts are assigned to co-products; however, even if an allocation were applied, such as milk solids allocation, which is the correct procedure in multioutput systems (Milani et al., 2011), the larger emissions of LM mozzarella compared with HM mozzarella will be invariant (results not shown).

Table 8 illustrates the comparison of emissions and the phases influencing differences between the $2 \mathrm{moz}-$ zarella types (dry basis). The farm phase effects were the same for both types because the same raw milk can supply both types of mozzarella, so the effect of raw milk variability was negligible, although the impact variability of milk production is well established and is the first contributor for environmental impacts (Guerci et al., 2013; Thoma et al., 2013). Notably, the farm phase analysis was not our study's goal. The postdairy plant phases were also identical to HM mozzarella with the exception of oven cooking at the consumption phase. Oven cooking determined the main differences between mozzarella types, and it was particularly related to electricity usage. Importantly, oven cooking is an assumption, so it may be possible to have different kinds of consumption phases, such as no cooking or a different way of cooking; however, considering the most common situation, LM mozzarella is mainly produced and used as a pizza topping, it is reasonable to consider oven cooking to represent the whole life cycle. For manufacturers, it is important to highlight the differences in the manufacturing processes, in that transport of curd led to larger effects of LM mozzarella over HM mozzarella. Ozone depletion, HT, POF, and land occupation were strongly influenced by transport. Additionally, curd cooking was the second source of the increase, having the greatest contribution for WD, $\mathrm{CED}, \mathrm{CC}, \mathrm{OD}, \mathrm{FE}$, and terrestrial acidification. Additional storage was the third-largest contributor to LM mozzarella effects. The extra plastic packaging used to package the curd and the waste generated from the additional operations of LM mozzarella production had minimal contribution to the impacts.

Generally, LM mozzarella is manufactured with purchased imported curd. The milk produced in Italy represents $70 \%$ of the whole Italian milk supply chain (CLAL, 2015), so Italy imports milk and curd to cover the whole national consumption. The $60 \%$ of Italian milk is used to produce high-quality and traditional cheese (CLAL, 2015); therefore, the majority of imported milk and curd is used to produce general industrial cheese, such as LM mozzarella. Transport of raw milk, other inputs, and mozzarella were all relevant contributors to several effects; moreover, they were the first cause of higher impacts of LM mozzarella than HM mozzarella from a gate-to-gate perspective. This situation suggests consideration of a scenario analysis where LM mozzarella is produced using raw milk $(\mathbf{L M m ~ m o z -}$ zarella) instead of curd. In this scenario, the foreign (94\%) and Italian milk is delivered to mozzarella plants and LMm mozzarella is produced normally, as in case of HM mozzarella; therefore, the additional phases to 
manufacture curd are avoided. Meanwhile, an increase in transport is required; in fact, generally $10 \mathrm{~kg}$ of milk is necessary to produce $1 \mathrm{~kg}$ of curd (Walstra et al., 2006). In this scenario, LMm mozzarella had higher emissions than LM mozzarella from a cradle-to-grave perspective (Figure 8), ranging from $38 \%$ for CED to $1 \%$ for land occupation. Clearly, the transport of raw milk played a fundamental role in increasing emissions; the transport of milk determined an increase, especially for OD, HT, and CED. This result suggests that the production of LM mozzarella using purchased curd is environmentally better than using imported raw milk. Although the curd production requires more manufacturing phases, the effects are not relevant when compared with the transport of imported milk, where the average transport was 1,397 and $103 \mathrm{~km}$ for foreign and Italian imported milk (the same as purchased curd), respectively. Therefore, in a hypothetical situation where the manufacturer has to decide to produce LM mozzarella purchasing curd or liquid milk, the more sustainable decision is to import curd, which requires less transport. In fact, curd production represents a kind of milk concentration, which is a practice that helps reduce impact from milk transport (Flysjö, 2012).

\section{CONCLUSIONS}

Our study is an LCA of Italian mozzarella cheese, and the processes and effects of the mozzarella manufacturing plants were emphasized because they can be easily controlled by the mozzarella manufacturer. In a cradle-to-grave perspective, animal feed production and raw milk production were hot spots for all impact categories except ozone depletion. Effort should be invested to reduce impacts from agricultural phases of the life cycle (reduction of methane emissions, improvement of manure management, and fertilization techniques), because improvements in these areas have the potential to significantly reduce several environmental impacts of the mozzarella life cycle. Energy and fuel usage were the main contributors for many manufacturing and post-dairy plant environmental burdens, which involved activities such as storage, refrigeration, and transport. Manufacturing and packaging had the largest post-farm contribution, with their largest influence being on freshwater and marine eutrophication, cumulative energy demand, and land occupation. Water used for cleaning, mozzarella production, and wastewater management had the greatest contribution to water de-

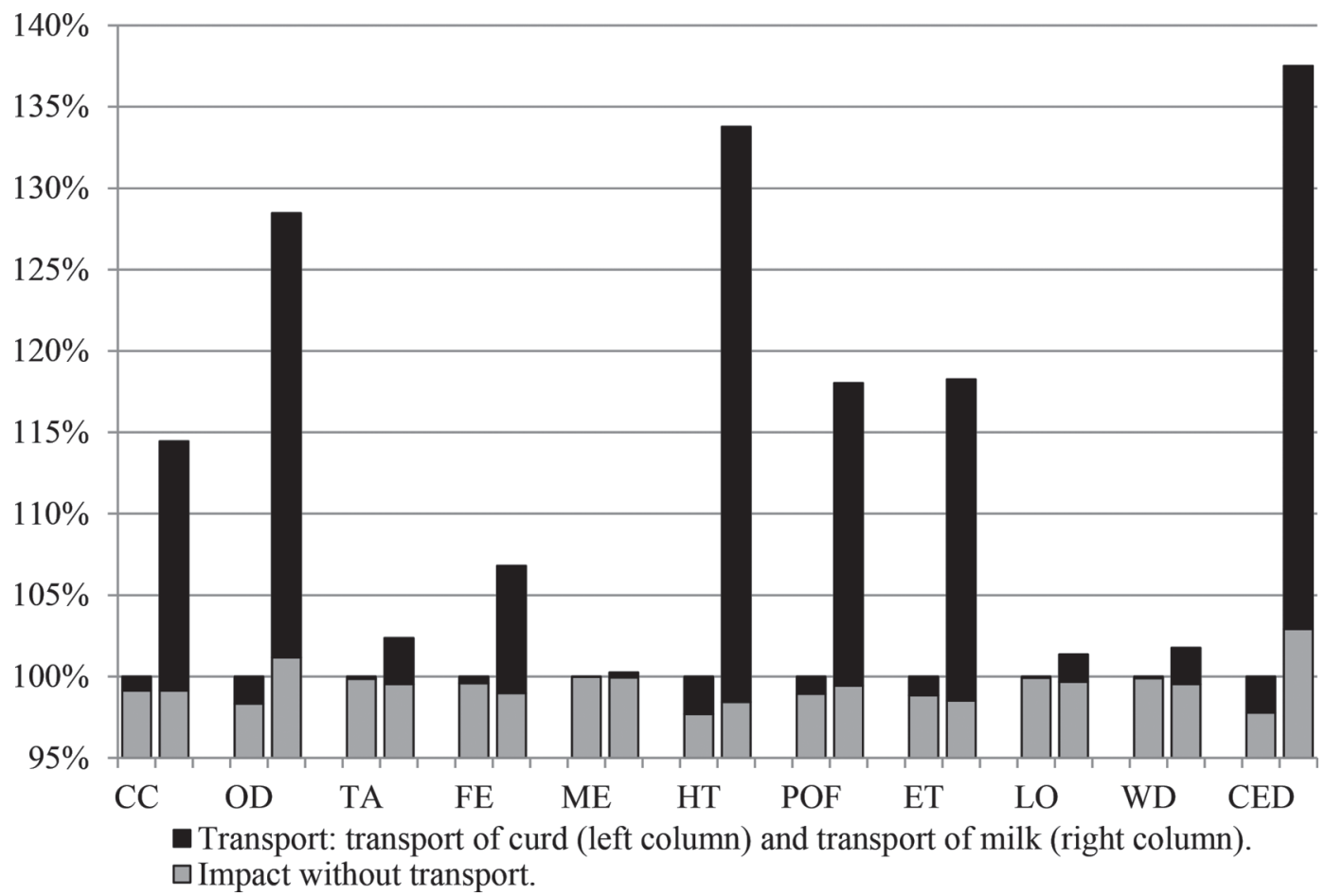

Figure 8. Comparison of low-moisture (LM) mozzarella (left column, 100\%) and an assumption of LM mozzarella produced from imported raw milk (LMm mozzarella; right column), respectively, from a cradle-to-grave perspective and a relative contribution of curd and milk. CC $=$ climate change; $\mathrm{OD}=$ ozone depletion; $\mathrm{TA}=$ terrestrial acidification; $\mathrm{FE}=$ freshwater eutrophication; $\mathrm{ME}=$ marine eutrophication; $\mathrm{HT}=\mathrm{hu}-$ man toxicity; POF = photochemical oxidant formation; ET = ecotoxicity; LO = land occupation; WD = water depletion; CED = cumulative energy demand. 
pletion and relevant contributions to marine eutrophication. Transport of milk and mozzarella was relevant for human toxicity and photochemical oxidant formation. Distribution, retail, house, and disposal phases had smaller contributions to final effects. Furthermore, this study analyzed the differences between mozzarella produced directly from raw milk (HM mozzarella) and mozzarella from purchased curd (LM mozzarella). The LM mozzarella had larger effects than HM mozzarella, particularly due to the additional transport to deliver the curd to mozzarella plants as well as the additional operations to process the curd into mozzarella, which were estimated as main contributors increasing the effects. However, comparing LM mozzarella production using curd or using imported milk from the same location of the curd, the results show that the more sustainable choice was to import curd instead of milk. In fact, milk import required much more transport, considering the liquid status of the milk. Overall, the production of mozzarella directly from raw milk appears to be more environmentally sustainable than using purchased curd. Moreover, HM mozzarella, being classified as a high-quality mozzarella - normally produced with Italian milk - can also obtain a Protected Designation of Origin label, which can improve the visibility of the HM mozzarella as having lower environmental burdens.

\section{ACKNOWLEDGMENTS}

The authors thank Trevisanalat Mozzarella Manufacturing Plant (Resana, Italy) for its support in providing critical data through the survey, and the National Breeders Association of Holstein Friesian Cattle (ANAFI) for support by funding the research.

\section{REFERENCES}

Assolatte. 2015. Italian Mozzarella market 2014. Cerved Business Information. Smart Mozzarelle Aprile 2015. Cerved Studi e Analisi. Accessed Oct. 3, 2016. https://know.cerved.com/it/studi-e-analisi. Ayer, N. W., P. H. Tyedmers, N. L. Pelletier, U. Sonesson, and A. Scholz. 2007. Co-product allocation in life cycle assessments of seafood production systems: review of problems and strategies. Int. J. Life Cycle Assess. 12:480-487.

Berlin, J. 2002. Environmental life cycle assessment (LCA) of Swedish semi-hard cheese. Int. Dairy J. 12:939-953.

Broekema, R., and G. Kramer. 2014. LCA of Dutch Semi-Skimmed Milk and Semi-Mature Cheese. Blonk Consultants, Gouda, the Netherlands.

Chiellini, E., ed. 2008. Environmentally Compatible Food Packaging. CRC Press, Boca Raton, FL. https://doi.org/10.1533/ 9781845694784 .

CLAL. 2015. Italia: Settore lattiero caseario. Accessed May 7, 2016. http://www.clal.it/?section=quadro_italia.

CLAL. 2016. Unione Europea: Settore lattiero caseario. Accessed Jun. 17, 2016. http://www.clal.it/?section=stat_ue15.

Dalla Riva, A., J. Burek, D. Kim, G. Thoma, M. Cassandro, and M. De Marchi. 2015. The environmental impact of cow milk in the northeast of Italy. Agric. Poljopr. 21:105-108. de Angelis. 2016. Estate: Birra, frutta e verdura, le regine del frigo degli italiani. 8 milioni di ettolitri di birra sorseggiati tra maggio e settembre. Consumi 2012 sempre più casalinghi: 6 bottiglie su 10 (57\%) finiscono nel nostro frigo. Accessed Jun. 17, 2016. http://www.birragustonaturale.it/uploads/201_06_19estate_birra frutta_e_verdura_le_regine_del_frigo_degli_italiani.pdf.

Ecoinvent. 2015. Ecoinvent 3.2 database. Swiss Centre for Life Cycle Inventories, Dübendorf, Switzerland. Accessed Jan. 25, 2016. http://www.ecoinvent.org/database/ecoinvent-32/ecoinvent-32 .html.

Eide, M. H. 2002. Life cycle assessment (LCA) of industrial milk production. Int. J. Life Cycle Assess. 7:115-126.

EPD. 2013. Dichiarazione Ambientale di prodotto della mozzarella da latte fresco alta qualità. CPC code $2225-$ Cheese, fresh or processed. Environmental product declaration, EPD System. Stockholm, Sweden. Accessed Jun. 5, 2016. http://www.environdec .com/en/Detail/epd128.

ERPC. 2014. European Recovered Paper Council. Paper recycling. Monitoring report 2014. Accessed May 15, 2016. http://www .paperforrecycling.eu/publications/.

FAO. 2006. Codex Standard (262-2006) for Mozzarella. Accessed Apr. 20, 2015 http://www.fao.org/input/download/standards/10749/ CXS_262e.pdf.

FAO. 2011. Global food waste and food losses. Extent, causes and prevention. FAO, Rome, Italy. Accessed Oct. 25, 2015. http://www.fao.org/fileadmin/user_upload/suistainability/pdf/ Global_Food_Losses_and_Food_Waste.pdf.

FAO. 2016. Environmental performance of large ruminant supply chains: Guidelines for assessment. Livestock Environmental Assessment and Performance (LEAP) Partnership. FAO, Rome, Italy. Accessed Nov. 25, 2016. http://www.fao.org/3/a-av152e.pdf.

Finnegan, W., J. Goggins, E. Clifford, and X. Zhan. 2015. Global warming potential associated with dairy products in the Republic of Ireland. J. Clean. Prod. 163:262-273. https://doi.org/10.1016/ j.jclepro.2015.08.025.

Flysjö, A. 2011. Potential for improving the carbon footprint of butter and blend products. J. Dairy Sci. 94:5833-5841.

Flysjö, A. 2012. Greenhouse gas emissions in milk and dairy product chains. PhD Thesis. Science and Technology, Department of Agroecology-Agricultural Systems and Sustainability, Aarhus University, Foulum, Tjele, Denmark.

Flysjö, A., C. Cederberg, M. Henriksson, and S. Ledgard. 2011. How does co-product handling affect the carbon footprint of milk? Case study of milk production in New Zealand and Sweden. Int. J. Life Cycle Assess. 16:420-430. https://doi.org/10.1007/s11367-011 -0283-9.

Flysjo, A., M. Thrane, and J. E. Hermansen. 2014. Method to assess the carbon footprint at product level in the dairy industry. Int. Dairy J. 34:86-92.

Foster, C., K. Green, and M. Bleda. 2007. Environmental impacts of food production and consumption: Final report to the Department for Environment Food and Rural Affairs. Manchester Business School. Defra, London, UK.

Frischknecht, R., N. Jungbluth, H. J. Althaus, G. Doka, T. Heck, S. Hellweg, and G. Wernet. 2007. Overview and Methodology. Ecoinvent Report No. 1. Swiss Centre for Life Cycle Inventories, Dübendorf, Switzerland.

Goedkoop, M., R. Heijungs, M. Huijbregts, A. D. Schryver, J. Struijs, and R. Jelm. 2009. ReCiPe 2008. A Life Cycle Impact Assessment Method Which Comprises Harmonized Category Indicators at the Midpoint and the Endpoint Level. 1st ed. Report 1: Characterization. VROM, Den Haag, the Netherlands.

González-García, S., É. G. Castanheira, A. C. Dias, and L. Arroja. 2013a. Environmental performance of a Portuguese mature cheesemaking dairy mill. J. Clean. Prod. 41:65-73. https://doi.org/10 .1016/j.jclepro.2012.10.010.

González-García, S., A. Hospido, M. T. Moreira, G. Feijoo, and L. Arroja. 2013b. Environmental life cycle assessment of a Galician cheese: San Simon da Costa. J. Clean. Prod. 52:253-262. https://doi.org/10.1016/j.jclepro.2013.03.006. 
Guerci, M., M. T. Knudsen, L. Bava, M. Zucali, P. Schönbach, and T. Kristensen. 2013. Parameters affecting the environmental impact of a range of dairy farming systems in Denmark, Germany and Italy. J. Clean. Prod. 54:133-141. https://doi.org/10.1016/j .jclepro.2013.04.035.

Guinard, C., F. Verones, Y. Loerincik, and O. Jolliet. 2009. Environmental/ecological impact of the dairy sector: Literature review on dairy products for an inventory of key issues, list of environmental initiative and influences on the dairy sector. Bull. Int. Dairy Fed. 436:60.

IDF. 2015. A common carbon footprint for dairy, the IDF guide to standard lifecycle assessment methodology for the dairy industry. Bulletin of the International Dairy Federation, 479/20. International Dairy Federation, Brussels, Belgium.

ISO. 2006a. ISO 14040: Environmental management-Life cycle assessment-Principles and framework. International Organization of Standardization, Geneva, Switzerland.

ISO. 2006b. ISO 14044: Environmental management-Life cycle assessment-Requirements and guidelines. International Organization of Standardization, Geneva, Switzerland.

ISPRA. 2014. Rapporto Rifiuti Urbani-Edizione 2014. Dati di sintesi. Istituto Superiore per la Protezione e la Ricerca Ambientale Rapporti 202/2014. Istituto Superiore per la Protezione e la Ricerca Ambientale, Rome, Italy.

Istat. 2015a. La spesa per consumi delle famiglie, anno 2014 Statistiche report 8 luglio 2015. Accessed Jun. 5, 2016. http://www.istat.it/it/files/2015/07/COMUNICATO-CONSUMI .pdf?title $=$ Consumi + delle $+\quad$ famiglie $+-+08 \% 2$ Flug $\% 2 F 2015+-$ + Testo+integrale.pdf.

Istat. 2015b. Bilancio demografico nazionale, anno 2014. Statistiche report 15 giugno 2015. Accessed Aug. 10, 2016. http://www.istat it/it/archivio/149003

Kim, D., G. Thoma, D. Nutter, F. Milani, R. Ulrich, and G. Norris. 2013. Life cycle assessment of cheese and whey production in the USA. Int. J. Life Cycle Assess. 18:1019-1035. https://doi.org/10 .1007/s11367-013-0553-9.

Koeleman, E. 2015. Arla unveils you strategy, Growth is the key. Accessed April 7, 2016. http://www.dairyglobal.net/Articles/ General/2015/12/Arla-unveils-new-strategy-Growth-is-key $-2734026 \mathrm{~W}$.

Ledgard, S. F., J. Chobtang, S. Falconer, and S. McLaren. 2016. Life cycle assessment of dairy production systems in Waikato, New Zealand. Accessed Oct. 3, 2016. http://www.massey.ac.nz/ flrc/ workshops/16/Manuscripts/Paper_Ledgard_2016.pdf.

Marsh, K., and B. Bugusu. 2007. Food packaging-Roles, materials, and environmental issues. J. Food Sci. 72:R39-R55.

Milani, F. X., D. Nutter, and G. Thoma. 2011. Invited review: Environmental impacts of dairy processing and products: A review. J. Dairy Sci. 94:4243-4254. https://doi.org/10.3168/jds.2010-3955.

Nielsen, P. H., and E. Høier. 2009. Environmental assessment of yield improvements obtained by the use of the enzyme phospholipase in mozzarella cheese production. Int. J. Life Cycle Assess. 14:137-143.

Palmieri, N., M. B. Forleo, and E. Salimei. 2016. Environmental impacts of a dairy cheese chain including whey feeding: An Italian case study. J. Clean. Prod. 140:881-889. https://doi.org/10.1016/ j.jclepro.2016.06.185.
Plastic Europe. 2015. An analysis of European latest plastics production, demand and waste data. Accessed Apr. 25, 2016. http://www .plasticseurope.org/Document/plastics - the-facts-2015.aspx.

PRé Consultants. 2014. SimaPro 8.1, PRé Consultants, Amersfoort, the Netherlands. http://www.pre.nl/.

Ridoutt, B. G., S. Williams, S. Baud, S. Fraval, and N. Marks. 2010. Short communication: The water footprint of dairy products: Case study involving skim milk powder. J. Dairy Sci. 93:5114-5117. https://doi.org/10.3168/jds.2010-3546.

Rotz, C. A., F. Montes, and D. Chianese. 2010. The carbon footprint of dairy production systems through partial life cycle assessment. J. Dairy Sci. 93:1266-1282. https://doi.org/10.3168/jds.2009-2162.

Sonesson, U., and J. Berlin. 2003. Environmental impact of future milk supply chains in Sweden: A scenario study. J. Clean. Prod. 11:253-266. https://doi.org/10.1016/s0959-6526(02)00049-5.

STG. 2016. Disciplinare di produzione della specialita' tradizionale garantita "pizza napoletana". Accessed September 17, 2016 http://www.gazzettaufficiale.it/atto/serie_generale/caricaArticolo ?art .progressivo $=0 \&$ art.$i d$ Articolo $=1 \&$ art. versione $=1 \&$ art .codiceRedazionale $=04 \mathrm{~A} 05298 \&$ art .dataPubblicazioneGazzetta =2004-05-24\&art.idGruppo=0\&art.idSottoArticolo1 $=10 \&$ art .idSottoArticolo=1\&art.flagTipoArticolo=1.

Thoma, G., J. Popp, D. Nutter, D. Shonnard, R. Ulrich, M. Matlock, D. S. Kim, Z. Neiderman, N. Kemper, C. East, and F. Adom. 2013. Greenhouse gas emissions from milk production and consumption in the United States: A cradle-to-grave life cycle assessment circa 2008. Int. Dairy J. 31. https://doi.org/10.1016/j.idairyj .2012.08.013.

Trevisan, M., and S. Corrado. 2014. I Georgofili. Quaderni 2014-III Prodotti a denominazione di origine. Fattore di competitività e qualità: i formaggi. Pag.65. Firenze, 2 Dicembre 2014. Edizioni Polistampa, Florence, Italy.

Vergé, X. P., D. Maxime, J. Dyer, R. Desjardins, Y. Arcand, and A. Vanderzaag. 2013. Carbon footprint of Canadian dairy products: Calculations and issues. J. Dairy Sci. 96:6091-6104. https://doi .org/10.3168/jds.2013-6563.

Walstra, P., J. T. M. Wouters, and T. J. Geurts. 2006. Dairy Science and Technology. CRC Press, Boca Raton, FL.

Weidema, B. P., Ch. Bauer, R. Hischier, Ch. Mutel, T. Nemecek, J. Reinhard, C. O. Vadenbo, and G. Wernet. 2013. The ecoinvent database: Overview and methodology, Data quality guideline for the ecoinvent database version 3. Accessed Jun. 3, 2016 https://www.ecoinvent.org/files/dataqualityguideline_ecoinvent _3_20130506.pdf.

Williams, H., and F. Wikström. 2011. Environmental impact of packaging and food losses in a life cycle perspective: A comparative analysis of five food items. J. Clean. Prod. 19:43-48.

WRAP. 2014. Tom Quested and Liam Murphy. Household food and drink waste: A product focus. Accessed Jul. 27, 2016. http://www.wrap.org.uk/sites/files/wrap/Product-focused $\% 20$ report\%20v5_3.pdf.

WULCA. 2017. The AWARE method. Consensual Method Development, WULCA Group. Accessed Feb. 17, 2017. http://www.wulca -waterlca.org/project.html. 